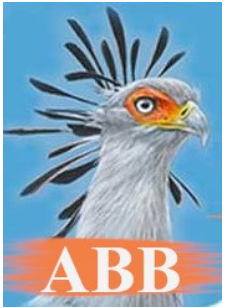

\author{
Afrotropical Bird Biology \\ Journal of the Natural History of African Birds
}

Volume 1

\title{
Birds and birding 2013-2020 at Macaneta, southern Mozambique
}

\author{
Gary Allport \\ c/o BirdLife International, The David Attenborough Building, Pembroke Street, Cambridge, CB2 3QZ, United \\ Kingdom. Email: Gary.Allport@birdlife.org
}

\begin{abstract}
The Macaneta area lies in the Incomati River estuary in northern Maputo Bay, Maputo Province, southern Mozambique. The $56 \mathrm{~km}^{2}$ study area follows no formal boundaries and comprises a $10 \mathrm{~km}$ stretch of ocean beach, coastal dunes with patchy thicket forest, and wet grasslands inland. The peninsula of Praia de Macaneta is also included in the study site but with few data. Improved access to the site in Oct 2016 enabled over 200 field surveys Oct 2016-Oct 2020 and the sightings are analysed and reported herein. A total of 295 species was recorded including eight globally threatened birds (three Endangered, five Near-threatened) and internationally important numbers of White-breasted Cormorant Phalacrocorax carbo and Whiskered Terns Chlidonias hybrida were found. Three new birds for Mozambique were discovered; Sharp-tailed Sandpiper Calidris acuminata (first for Africa), Whiterumped Sandpiper C. fuscicollis and Pearl-breasted Swallow Hirundo dimidiata. An annotated checklist of selected species is presented. The Sharptailed Sandpiper drew much birder interest with 254 international visitor days over the 12 weeks of its first visit Feb-Apr 2018, contributing over US\$12,000 to the local economy. The bird returned for two further seasons but it was not possible to gather further visitor data.
\end{abstract}

Keywords: birds, bird records, birding tourism, birding tourism revenue, annotated checklist, Macaneta, Mozambique Received: 19 March 2021; Accepted: 30 March 2021

https://doi.org/10.15641/abb.v1i.1066

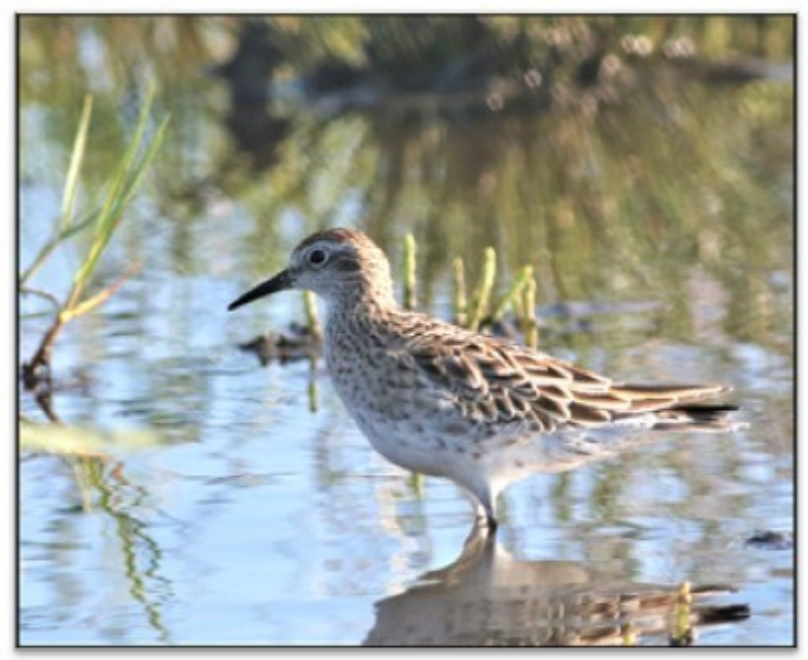

Figure 1. Sharp-tailed Sandpiper Calidris acuminata, Macaneta, Mozambique. The 'signature bird' which put Macaneta on the map, drawing hundreds of birders and making it a new choice location on birding tourism itineraries. Photo: G. Allport.

\section{Introduction}

Read et al. (2014) highlighted that avifaunal studies in southern Mozambique, particularly those concentrating on a specific area, remain sparse. Aside from the general accounts of Rosa Pinto and Lamm (1953, 1955, 1956, 1960), Clancey (1996) and Parker (1999), the only detailed sitespecific bird studies for Sul do Save (that part of southern Mozambique south of the Save River) are the annotated check-lists for Maputo Special Reserve (Parker and de Boer 2000), Inhaca Island (de Boer and Bento 1999) and Banhine
National Park (Pietersen and Pietersen 2010). In particular, our knowledge of numbers, seasonal fluctuations and distribution of waterbirds along the southern Mozambican littoral is meagre, although it is obvious that there are sites of global and regional importance for waders in this sector (e.g. the Bazaruto Archipelago, see Koehler and Koehler 1996). Likewise, the waterfowl and associated freshwater birds of southern Mozambique remain poorly studied, although Milstein (1984) and Dutton (1987) identified significant freshwater wetlands for birds in this region. 


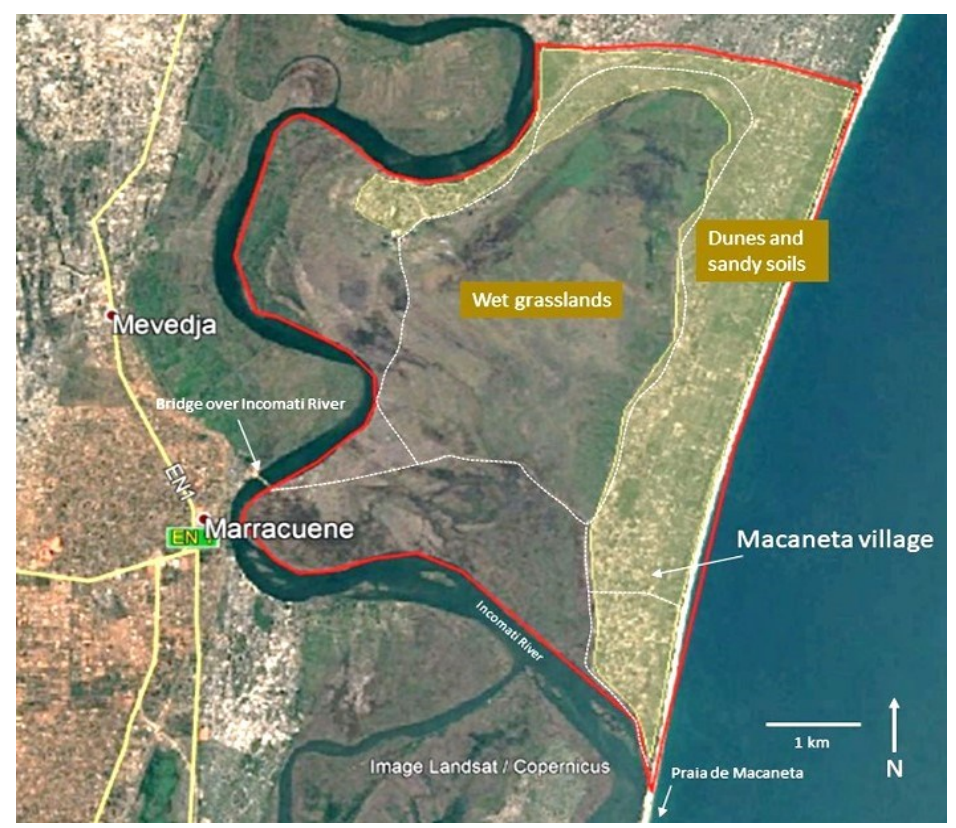

Map 1. The main study area (delineated in red, $56 \mathrm{~km}^{2}$ ) at Macaneta, showing the extent of the dune and sandy soil habitats (shaded yellow, $\left.18.2 \mathrm{~km}^{2}\right)$, and wet grasslands $\left(37.4 \mathrm{~km}^{2}\right)$. Access tracks regularly used in bird observations are shown in broken white lines. Note Praia de Macaneta lies to the south - see Map 2. Map data @2020 Google.

In 2016 the construction of a new bridge over the Incomati River at Marracuene greatly improved access to an area of tidal, high, saline and brackish marsh in the Incomati Estuary, in the northern part of Maputo Bay, allowing regular birding in these habitats, which are otherwise difficult to access in southern Mozambique, for the first time (Allport 2018a). A range of wetland birds such as Fulvous Dendrocygna bicolor and White-faced ducks $D$. viduata were found to be abundant and birds such as Baillon's Crake Porzana pusilla, previously little known in Mozambique (Clancey 1996), were found in in the wetlands around the village of Macaneta (2544'05.83"S; 3243'20.49”E). In Feb/Mar 2018 two Sharp-tailed Sandpipers Calidris acuminata were found in this area, the first record in continental Africa (Allport 2018a), and this drew attention to the site leading to regular visits by birders. The body of sightings information quickly grew as the area was explored more widely.

The improved access afforded by the new bridge to this previously little-developed stretch of coastline of high natural beauty also led to rapid human development. The purpose of this paper is to summarise ornithological knowledge of the area based on the few historical records and present an analysis of recent sightings (2016-2020), firstly as a source of information for visiting birders, but secondly, as a baseline for biodiversity assessment that can inform important development decisions which are likely to be taken in the near future. The economic value of birders visiting the site was also studied. A full analysis will be published elsewhere, but basic numbers based on simple data gathering are given here.

The recent observations show that the Macaneta area is an important locality for waterbirds, for certain forest-dwelling species and for rare and charismatic species that act as a powerful draw for ecotourists.

The general conservation importance of the Macaneta area has been recognised in the past but this paper further highlights the extraordinary biodiversity value of the site.

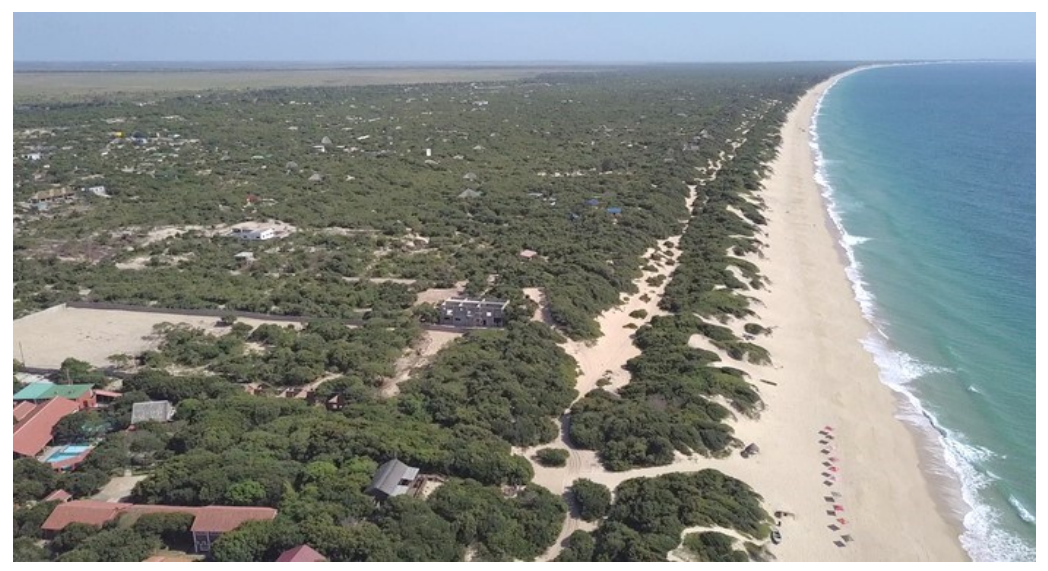

Figure 2. View north from Macaneta village with dune thickets in the foreground and wet grasslands behind. 


\section{Study area}

The main site is $56 \mathrm{~km}^{2}$ in extent (Map 1) and comprises low lying grassland in the south and west, abutting a $10 \mathrm{~km}$ long barrier dune system the length of the coastal eastern side, 1.2-1.5 km in width, which forms an arc inland westward across to the Incomati River on the northern edge of the study area. The sandy habitats are elevated up to c. $10 \mathrm{~m}$ and cover $18.2 \mathrm{~km}^{2}(33 \%)$ of the study area; the extent of the wet grasslands is $37.4 \mathrm{~km}^{2}$. The inshore marine area visible from the coast was included in the study area.

\section{Vegetation}

No vegetation studies were undertaken as part of this work but a brief description of the main vegetation types are given below (following Wild and Barbosa 1967 and Burrows et al. 2018).

Dunes - where undisturbed, the coastal dunes are clothed with dense, salt- and wind-clipped Littoral/ Dune ThicketForest (characterised by the winter fruit-bearing Coastal Red Milkwood Mimusops caffra) on the seaward side with small patches of Maputaland/ Licuati Sand Thicket landward in sheltered areas of older dunes (Fig. 2), and also along the banks of the Incomati River in the north-western-most area of the site. Local people have established properties on the rough reddish and sandy soils of the landward dune areas planting Coconut Palms Cocos nucifera, Mangos Mangifera indica and Cashew Trees Anacardium occidentale.

More intact forest is mostly in the grounds of the tourist lodges.

Lowland wet grasslands - the low-lying western and southern areas of the site comprise rich organic soils which are farmed on the slightly higher areas in a belt bordering the sandy soils along the landward edge of the dunes.

Cassava Manihot esculenta, Rice Oryza glaberrima and other crops are grown in small-scale strip agriculture.

The majority of the extensive low lying area comprises flat Hygrophilous Coastal Grassland which is almost treeless but with a c. 300 ha stand of Fever-Tree Thorn Acacia xanthophloea and exotic Eucalyptus sp. on an area of slightly higher ground in the southern-most part of the site. Hydrophyte formations are composed of Phoenix reclinata, Syzygium cordatum, Voacanga, Phragmites, Cyperus, Juncus spp. and Pteridium aquilidum on the dark, organic rich and hydro-morphological soils (see Hoguane and Antonio 2016 for more detail). The vegetation communities on the southern side of the road from Marracuene to Macaneta are dominated by large stands of Phragmites which are cut for domestic use by local people.

The extent of this harvesting, evident from Google Earth imagery, varies significantly between years. The wet grasslands are grazed by cattle in three main herds based from locations at Macaneta village, cattle corrals in the southwest of the site and from a village at the northern edge of the site. Each herd is of $80-150$ animals ranging daily from these locations returning in the evenings.

The area south of and adjacent to the MarracueneMacaneta road for the $1 \mathrm{~km}$ west of Macaneta village holds low-lying halophytic plant communities dominated by patches of Salicornia sp. amongst open mud and shallow pools which flood on spring tides.

There are a few mangroves Rhizophera sp. and Avicenna $\mathrm{sp}$. in the south-eastern-most part of the site, along the landward river shoreline and on islands in the river. A narrow strip of mangroves are also found on the western side of Praia da Macaneta, broadening as the salinity increases southwards.

\section{Hydrology}

Initial studies of the hydrology of the wet grasslands suggests a complex pattern of fresh and saline water inflows varying with tides, seasonal rainfall and episodically with major climate events such as Tropical Storms.

Saraiva Okello et al. (2015) reviewed rainfall and river flows in the Incomati catchment 1950-2011. They found the variability of rainfall across the basin was high, both intra- and inter-annually, and the temporal variability of river flows was also high. They found significant declining trends in October flows, and in low flow indicators, however, no trends were evident in the other parameters, including high flows. Climate change effects are likely to be having an impact but Saraiva Okello et al. (2015) concluded that land use and flow regulation have been larger drivers of temporal changes in streamflow than climatic forces up to 2015. Overall this is described as a 'stressed' water resource system.

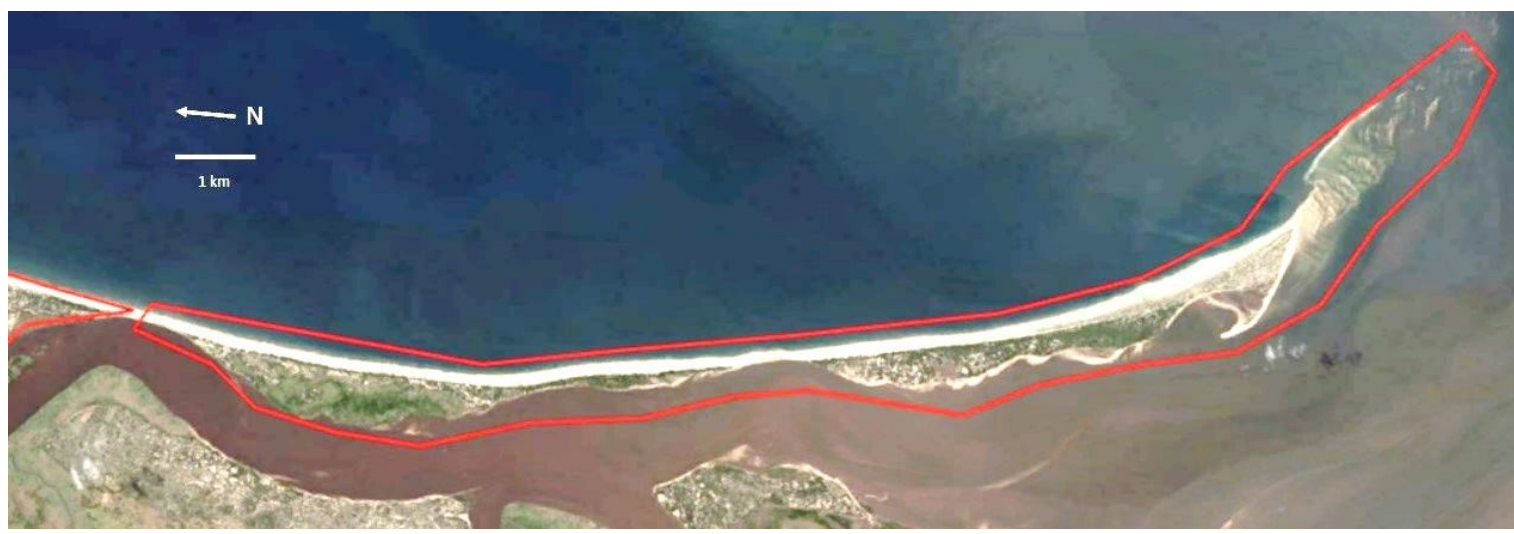

Map 2. Praia de Macaneta $\left(10.3 \mathrm{~km}^{2}\right)$ is a $12 \mathrm{~km}$ long sand spit with mangroves and some intertidal mudflat extending south from the main study site. The northernmost neck of the spit - left on the map above - is overtopped in storms (see text). The area remains little explored by ornithologists. Map data $\odot 2020$ Google. 
The intrusion of saline water from the mouth of the Incomati River varies with incoming tides versus outward freshwater flow. According to Gonzalez and Serraventosa (1999) and Hoguane (2002), salt intrudes $40-80 \mathrm{~km}$ upstream in the Incomati River estuary (measured from the tip of Praia da Macaneta).

However, Hoguane and Antonio (2016) measured salinity at 24 locations from the tip of Praia da Macaneta up to $30 \mathrm{~km}$ upstream in March and June 2002, and found that salinity decreased to less than $1 \mathrm{ppm}$ at $19 \mathrm{~km}$ upstream in both dry and wet seasons, which is downstream of the main study site described herein (for reference the bridge at Marracuene is $22 \mathrm{~km}$ upstream). Despite these measurements, their modelling suggested salt water intrudes $22-25 \mathrm{~km}$ upstream in periods of low freshwater flow.

The narrow neck of the beach in the northern part Praia da Macaneta (Map 2) is regularly overtopped on high tides and in storms introducing saline water into the estuary $12 \mathrm{~km}$ upstream.

It is possible that this neck could breach permanently which would create a new river mouth and if so the study site would be exposed to greater tidal range and intrusion of salt water.
Recent studies of coastal dynamics are contradictory; Karlsson and Liljedahl (2015) suggest a permanent breach is likely imminently but DHI (undated) suggest not. Historical maps from the late 19th century show the river mouth was formerly open to the sea at this location.

The wet grasslands comprise three local drainage basins within the site each with differing hydrology.

1. South-east Tidal Basin (Map 3A., Fig. 3, 372 ha) - this area is flooded by tidal waters entering from the main river via two channels, inflow running northwards bringing lowsalinity water from the estuary onto the wet grassland area.

Observations of water flow show that the tide raises water levels in the Salicornia dominated communtiies along the roadside but only on the highest full and new moon tides in October-March. Saline and hyper-saline water (probably generated by evaporation in temporal pools) is thus pushed into the area (O. Hamerlynck pers. comm. 2019) and tidal waters flow through culverts under the road and onto the grassland in the Central Basin of the site. In periods of very high tides this flow between basins has been observed to be continuous for 3-4 days.

The level and extent of water in the majority of this basin is mainly reliant upon tides.
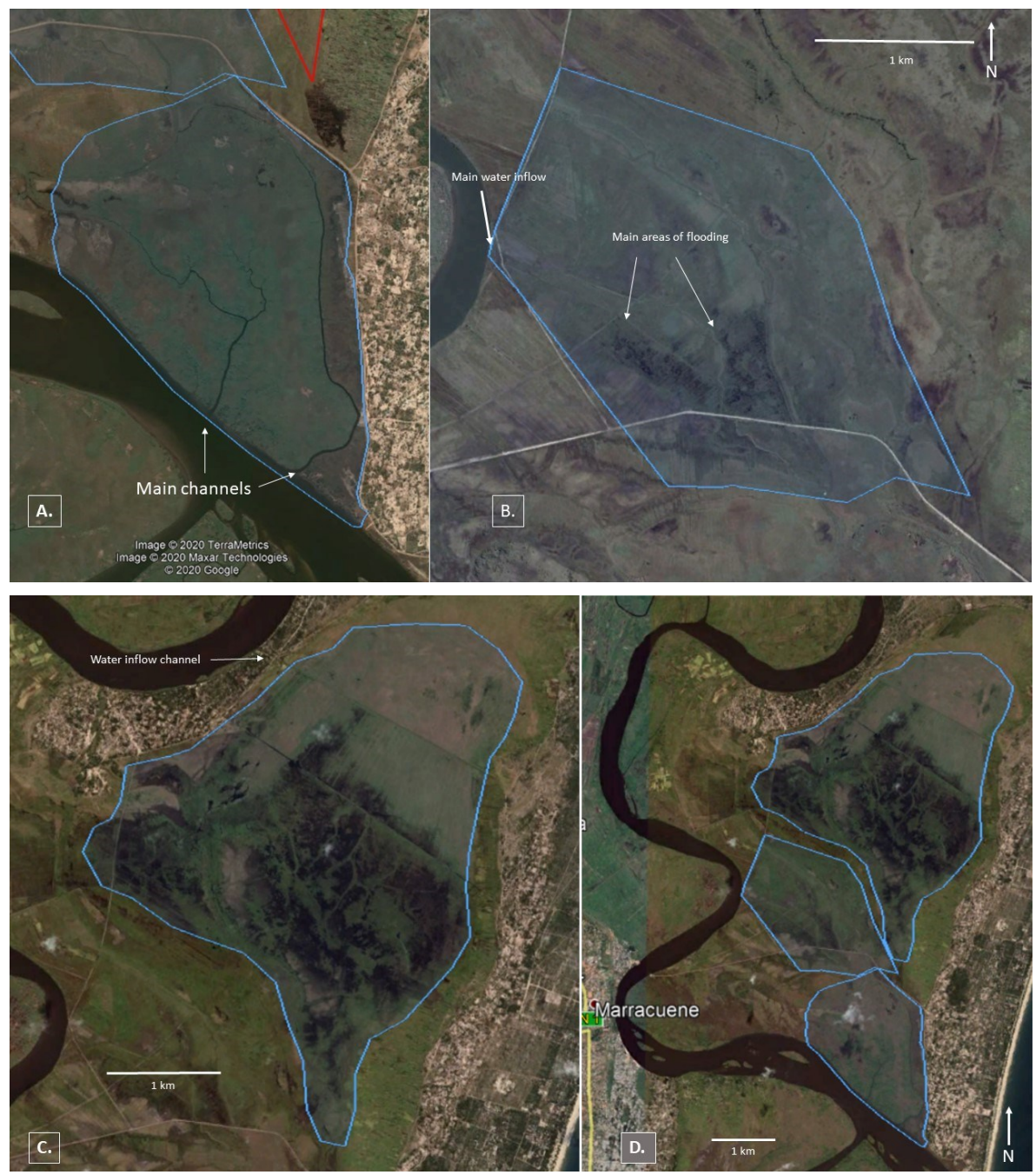

Map 3. Location of three main local drainage basins within the Macaneta wetlands (outlined in blue). A. South-east Tidal (372 ha), B. Central Basin (369 ha) and C. Northern Basin (1,170 ha). D. shows the location of the three local drainage basins at site level. Image date 3 May 2015; note extensive floodwater in C. Map data @2020 Google. 


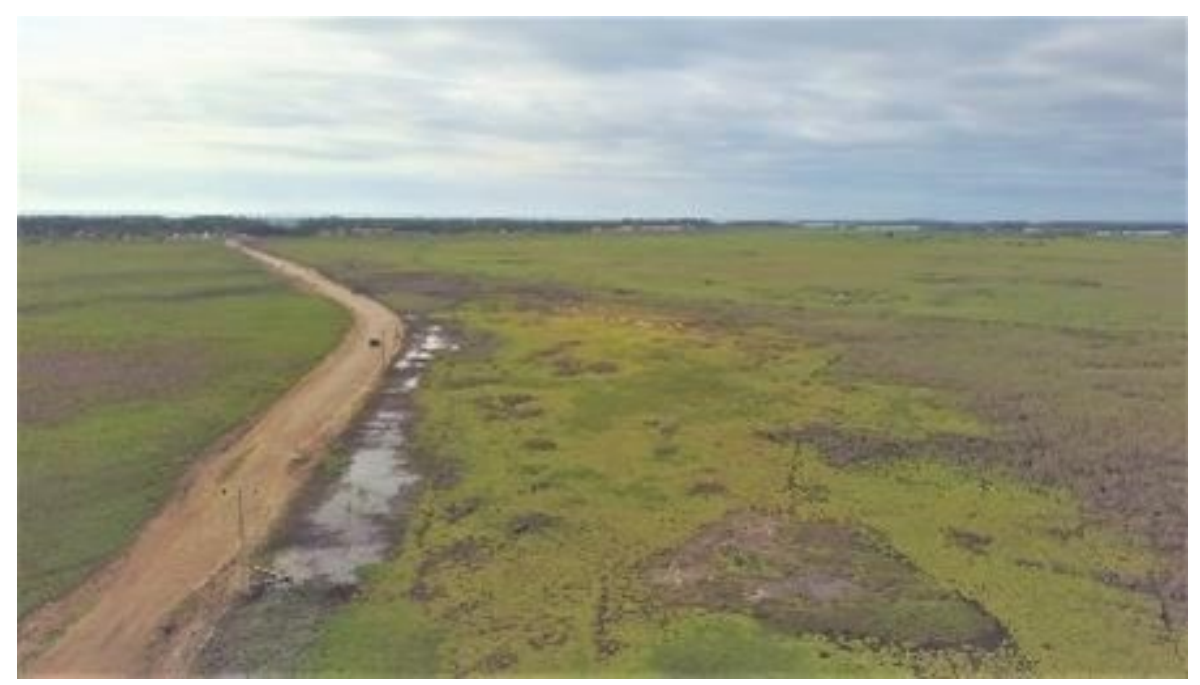

Figure 3. South-east Tidal Basin. View to the south-east with Salicornia dominated open pans in the foreground, tidal reed beds behind and dune thicket around Macaneta village on the horizon. The saline pans are used by waders for roosting and high-tide feeding on spring tides. This is the main locality for sightings of Sharp-tailed Sandpiper; "The Sharpie Spot".

2. Central Basin (Map 3B. Fig. 4, 369 ha) - some water enters this highly dynamic area from the saline marsh to the south on large spring tides, but water mainly enters from the river to the north at a point where it is likely to be fresh or of very low salinity (24 km upstream). In times of high river levels due to rainfall run off and/ or high tides this wetland area is recharged and holds standing water for weeks or months at a time; but this area does also dry out completely.

3. Northern Basin (Map 3C., 1,170 ha) - some saline water flows into the very southern end of this basin on spring tides, but the main entry point is of river water through a manmade channel cut through the dunes at the northern end enabling fresh water to enter over a non-return, drop-board sluice gate which acts to hold the level once water has flowed into the area from the river. This basin is also highly variable in water level and extent of flooding but examination of Google Earth images 1989-2020 shows that there is always some standing water in the northern-most sector, even in the driest of times.

\section{Fauna}

Humpback Whales Megaptera novaeangliae are regularly seen 2-5 km offshore July-October and a single Indian Ocean Humpback Dolphin Sousa plumbea was photographed close inshore associating with local fishermen in 14 Sep 2020 (M. Drummond pers. comm. 2020). It is also worth noting for the future that Maputo Bay did once hold a breeding population of Southern Right Whale Eubalaena australis which was depleted by whaling in the late 18th century to extinction in 1805 (Richards R and Du Pasquier 1989). With the recovery of this species and recent sightings in Mozambique (Banks et al. 2011) it may return to breed in the Macaneta inshore marine area.

Vervet Monkey (Cercopithecus pygerythrus), Samango Monkey (Cercopithecus mitis), Thick-tailed Galago (Otolemur crassicaudatus) and Common Large-spotted Genet (Genetta maculata) have all been recorded from the dune forests (GA pers. obs.).

The wet grasslands hold at least five pairs of Side-striped Jackals Canis adustus. Foot prints of Water Mongoose Atilax paludinosus are abundant in the soft muddy areas but there have only been three sightings (GA pers. obs, J. Nicolau pers. comm. 2019). Serval Leptailurus serval has been sighted twice and African Wild Cat once Felis lybica (GA pers. obs, J. Nicolau pers. comm. 2019).

The indigenous, fast growing Mozambique Tilapia Oreochromis mossambicus rapidly enter newly flooded areas, often visibly abundant in roadside ditches 10-14 days after water levels rise (O. Hamerlynck and R. Bills pers. comm. 2019).

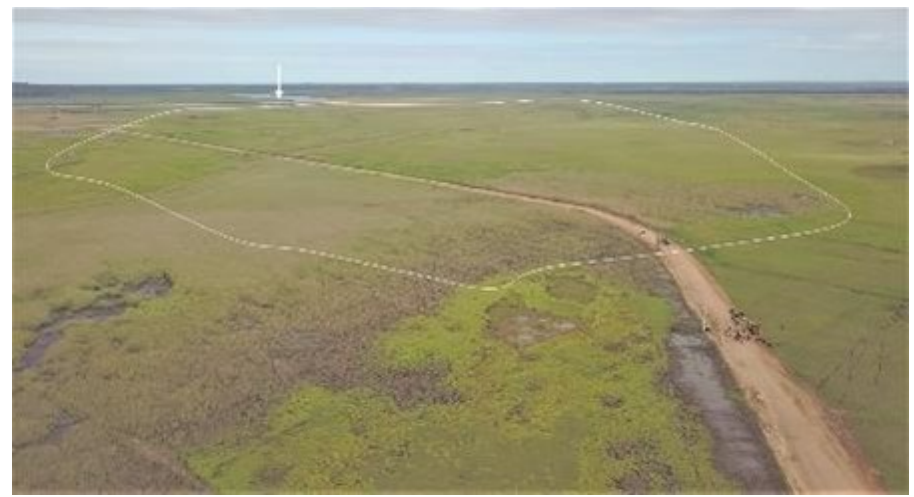

Figure 4. Central Basin (outlined in white). View north-west (photo taken from same location as Fig. 3) with saline pans in the foreground (in the South-east Tidal Basin), extensive reed beds and grazed open wet grassland behind. Main inflow from Incomati River indicated by arrow. This area is highly dynamic and attracts numerous waterbirds when flooded (e.g. 5,000+ ducks, ibises and waders Jan 2018). 


\section{Methods}

Field observation methods

The area was initially visited by $\mathrm{E}$. Marais and M. Ngwenyama in May 2013 as part of an assessment of Mozambique's birding ecotourism potential (see https://www.cepf.net/sites/ default/files/finalreport-blsa-61525.pdf). The site was found to be of birding interest but access was limited by the ferry crossing of the river at Marracuene. GA made five follow-up trips July-Nov 2015 but difficulty in access hampered further site visits. BB made four visits in 2016 (with ES on one visit). Access to the area was greatly improved when the new bridge across the Incomati River at Marracuene was opened in November 2016, however, travel was still slow from Maputo as connecting roads were under construction, but in Nov-Dec 2017 BB was able to visit the site in short half-day trips from Maputo for the first time. GA followed with a series of site visits in Dec 2017 and Jan 2018.

It was clear that the birding on the site was of high quality and observations were logged on eBird and Birdlasser/ SABAP and posted on the Birds Mozambique Facebook page. Both local and visiting birders commenced regular observations and on 18 Feb 2018 a Sharp-tailed Sandpiper was found in the saline Salicornia marshland near Macaneta village (Allport 2018a). A new bird for Africa, the bird drew many birders to the site over the following two months of its initial stay. This led to significantly increased coverage and further exploration of the site as birders stayed at tourist lodges in the coastal forested area.

All birders were encouraged to log their records with eBird and/or Birdlasser SABAP. An eBird hotspot was created "Macaneta-- Wetland, dune forests and coast" (here: https:// ebird.org/hotspot/L7097882) to ensure birders submitted records to one eBird location consistently, to quickly see recent postings and lists of birds seen, and to afford subsequent ease of analysis.

Wider exploratory birding was undertaken ranging to the northern end of the site by vehicle (EM and GA) and two boat trips were taken from a dock in the channel near
Macaneta, upstream to explore the Fever-Tree Thorn grove (25 $\left.44^{\prime} 17.0^{\prime \prime S} 32^{\circ} 42^{\prime} 00.4^{\prime \prime E}\right)$ on 14 July 2018 and to the tip of Praia da Macaneta 26 Aug 2018 (GA/ CC).

A regular day visit routine emerged, starting by entering the site by car pre-dawn via the main track either from Marracuene or from the coastal lodges in the dune forest, looking for nocturnal species, calling crakes etc., and in order to be in the wetland area to observe and count the morning flight of waterbirds. It became clear that spring tides were an important opportunity to observe waders in the South-east Tidal Basin as shorebirds were pushed out of the tidal wetland in the first two hours after dawn, often easily visible roosting and feeding along the roadside wetlands.

A spring high tide wader roost was also located near Macaneta village and this was counted as frequently as possible. Where possible a visit to the dune forest around the lodges was made and a mid-morning 'lift-off' of soaring birds was also monitored (c.10am), including a notable flight line of raptors, storks, pelicans, etc., along the bluff to the west of the site, visible from the new bridge at Marracuene. Breeding species such as Little Bitterns Ixobrychus minuta and Collared Pratincoles Glareola pratincola were also monitored where possible. In the winter dry season the open grasslands became drier and more accessible via a motorable track known as 'The Diagonal' from Macaneta village NW through the Central and Northern Basins. This afforded good views of bustards, longclaws and cisticolas. Secretive grassland birds were also sought by groups walking line abreast through likely looking habitat.

\section{Bird observation analyses}

A total species list was generated from eBird, and SABAP data. Bar charts were generated for all species in eBird records using an algorithm showing the frequency of occurrence by week. The bar chart registered percentage frequency of the species recorded in the checklists for that week. Species of importance for their threatened status and concentrations in numbers on site were identified. An annotated checklist is given for select species of note.

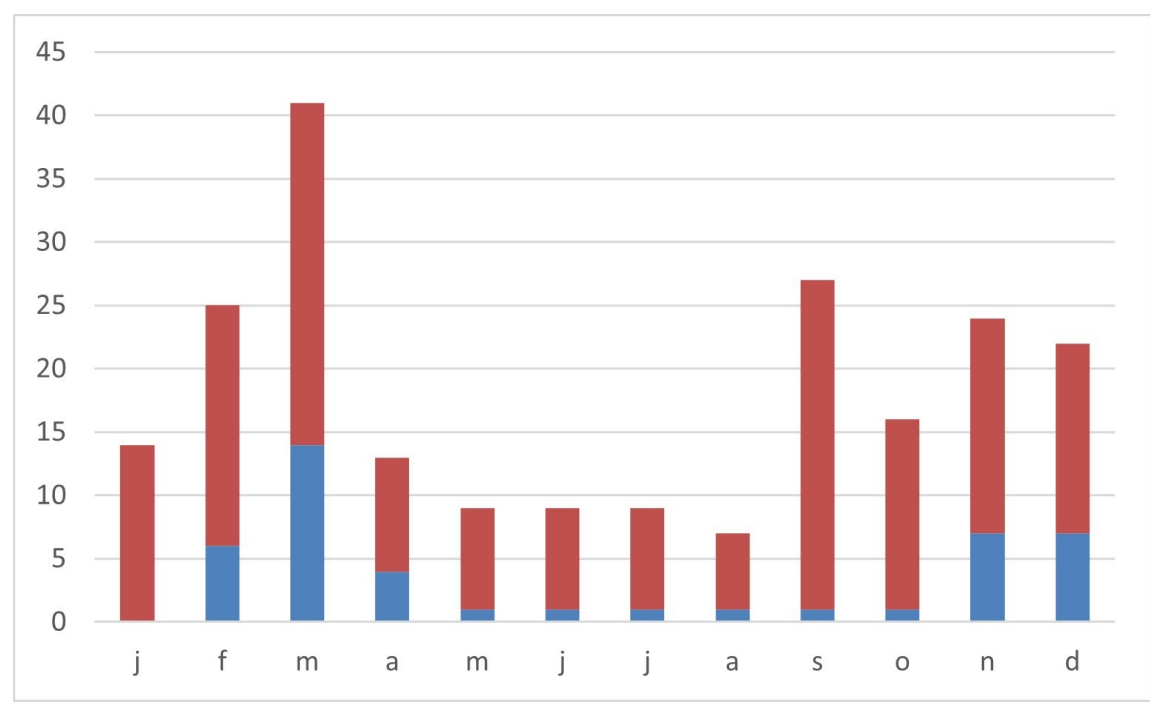

Figure 5. Count of bird observation records for Macaneta area by month $(n=216)$ submitted to SABAP (shown in blue; pentad 2540_3240; 22/5/2013-12/2/2020; 37 observers) and eBird (in orange; to Macaneta hotspot location; 10/4/2010-2/11/2020). 
Table 1. Top five locations ranked by bird species richness in Mozambique.

\begin{tabular}{|l|l|l|l|}
\hline Rank & Site & Total & Source \\
\hline 1 & Gorongosa National Park & 386 & eBird Hotspot \\
\hline 2 & Vilanculos Coastal Wildlife Sanctuary & 321 & Read et al. 2014, C. Read pers. comm. 2020 \\
\hline 3 & Macaneta-Wetlands, dune forest and coast & 295 & eBird Hotspot, this study \\
\hline 4 & Rio Savanne wetlands & 281 & eBird Hotspot \\
\hline 5 & Dunes de Dovela & 270 & eBird Hotspot \\
\hline
\end{tabular}

\section{Birding visitor data}

The Sharp-tailed Sandpiper attracted birders to the site wishing to see it. Considerable effort was made to enable visitors to visit the site by providing up-to-date information, recommending accommodation and other travel services. An attempt was made to record the number and details of visitors in the period Feb-Apr 2018, gathering basic information on dates of visit, nationality, residence location, means of transport, accommodation (venue, bed nights) and other travel services used (guide, vehicle hire). Analyses of these data will be published elsewhere but basic results are given here.

\section{Coverage}

Field observation data were logged through Birdlasser to the SABAP database and to eBird. There was complete coverage of all months of the year but relatively low May-Aug (Fig. 5). There were 44 SABAP data cards from 37 observers, and 172 eBird logs, a total of 216 entries. However, there was duplication as some observers entered data into both systems, and different members of multi-person birding parties sometimes entered separate lists. It was not feasible to correct for this duplication but it is estimated that over 200 separate observer-visits were entered into the two systems, and the data presented accurately reflects the overall coverage and the pattern of recording.

\section{Results}

Species richness

The avifauna of the Macaneta area is diverse with 295 species recorded to date (Ashy Flycatcher Muscicapa caerulescens in SABAP data only [pentad 2540_3240]; White Stork Ciconia ciconia recorded in a personal eBird location not the Macaneta hotspot and do not therefore appear in Annexe 1) and this total is likely to continue to increase with further observer effort. The site ranks third in bird species richness in Mozambique (Table 1) after Gorongosa National Park and the Vilanculos Coastal Wildlife Sanctuary (Read et al. 2014, C. Read pers. comm. 2020). The area thus holds the richest avifauna of any known unprotected site in Mozambique.

\section{Species relative frequency (eBird "Bar Chart")}

Annexe 1 presents bar charts of relative frequency of occurrence all 292 species recorded in the eBird Hotspot by week (this annexe also provides the scientific names of species mentioned).

Note there are three of the week periods without field data which are shown in grey in the diagrams. Seasonal patterns of occurrence are evident from the bar charts, most of which fit with well-known trends for the region, and are outlined in general below.

\section{Seasonality of occurrence}

Waterbirds - southern Mozambique is a region of summer rainfall with a main arrival of waterbirds as wetlands are hydrated by both direct rainfall and runoff November-April. This was clearly evident for ducks, geese, rails, crakes, gallinules, herons and other waterbirds most of which arrived on the site starting in November, with all species present by late-December.

These species were recorded until water levels fall in AprilMay. Numbers of waterbirds were spectacular at times, with, for instance, $5000+$ waterbirds on site in early February 2018 including 2000 White-faced and 500 Fulvous ducks, 700 Glossy Ibises, 1000+ egrets and 500 Ringed Plovers (GA; 4 Feb 2018 https://ebird.org/checklist/S42482033).

The site supports a healthy population of waterbirds that require marginal aquatic habitats but the lack of extensive open waters means that species such as Little Grebe and Red-knobbed Coot are rare, and other open-water birds that occur in the Maputo area, such as Cape Teal Anas capensis, have not been recorded. Similarly both Greater and Lesser flamingos occur in the Maputo Bay area (GA pers. obs.) but were only seen in either very small numbers in the Northern Basin, or overflying in groups. However, there has been a small group of Lesser Flamingos regularly reported from the Praia de Macaneta area but these were not recorded in this study.

Passage migrants - there were two periods when passage migrants or apparent passage migrants were most evident. Firstly, late October to mid-November when Afro-tropical migrant species such as Yellow-billed Kite, Black Sparrowhawk (although this species is not known to be a migrant in southern Africa - Hockey et al. 2005), Violet-backed Starling, Klaas' and Red-chested cuckoos passed through, along with Palearctic species such as Spotted Flycatcher and Red-backed Shrike.

The second passage period was March-early April when many of the Palearctic species seasonally resident for the austral summer departed and species such as Amur and Peregrine falcons, White-winged Tern, Red-backed and Lesser Grey shrikes were seen on passage at Macaneta. 
Table 2. Globally Threatened birds found at Macaneta (see http://datazone.birdlife.org/country/mozambique for more information).

\begin{tabular}{|l|c|}
\hline Species & Globally Threatened Red List category \\
\hline Cape Gannet Morus capensis & Endangered \\
\hline Cape Cormorant Phalocrocorax capensis & Endangered \\
\hline Spotted Ground Thrush Geokichla guttata & Endangered \\
\hline Pallid Harrier Circus pallidus & Near-threatened \\
\hline Great Snipe Gallinago media & Near-threatened \\
\hline Curlew Sandpiper Calidris ferruginea & Near-threatened \\
\hline Eurasian Curlew Numenius arquata & Near-threatened \\
\hline Lesser Flamingo Phoeniconaias minor & \\
\hline
\end{tabular}

Wintering species - in late April the last of the Palearctic migrants departed and a range of Afrotropical species arrived to be seasonally resident for the austral winter, some in small or gradually building in numbers, such as Mangrove Kingfisher, Red-faced Mousebird, Dark-capped Yellow Warbler, African Dusky Flycatcher and Lesser Masked Weaver, and others with a marked arrival such as Great White Pelican, Cape Wagtail (arriving just as Western Yellow Wagtails depart), African Stonechat and Black-bellied Bustard. Wattled and Black-bellied starlings arrived in large numbers to feed on the abundant berries of the Coastal Red Milkwood. Caspian Terns arrived at this time often with very young birds still begging for food from their parents.

\section{Globally threatened birds}

Four Endangered and five Near-threatened birds were found in the study area (Table 2.). See species accounts in the annotated checklist below for more details of each.

\section{Waterbird numbers}

Two waterbird species were present seasonally in numbers exceeding population thresholds of international importance as specified in the Ramsar convention (see https:// www.ramsar.org/): Whiskered Tern and White-breasted Cormorant (Table 3.). See accounts in annotated checklist for species details. The maximum number of each wader species counted at Macaneta is given in Table 4.

Table 3. Waterbirds present in Internationally Important numbers at Macaneta (following Ramsar $1 \%$ of biogeographic population criteria, data from Critical Sites Network Tool [CSNT] http://wow.wetlands.org/en ). Columns: $n=$ count of eBird checklists with species recorded; No.> th'hold, is the number of counts when the threshold was exceeded (see annotated checklist for counts data).

\begin{tabular}{|l|c|c|c|c|l|}
\hline Subspecies & Pop. estimate & $\mathbf{1 \%}$ Th'hold & $\mathbf{N}=$ & No. > th'hold & CSNT link \\
\hline $\begin{array}{l}\text { Whiskered Tern Chli- } \\
\text { donias hybrida } \\
\text { delalandii }\end{array}$ & $\begin{array}{c}\text { Southern Africa: } \\
5-15,000 \text { birds }\end{array}$ & $\begin{array}{c}85 \\
\text { birds }\end{array}$ & 141 & 5 & $\frac{\text { http://wpe.wetlands.org/ }}{\text { view/1281 }}$ \\
\hline $\begin{array}{l}\text { White-breasted Cormo- } \\
\text { rant Phalacrocorax } \\
\text { carbo lucidus }\end{array}$ & $\begin{array}{c}\text { Coastal Southern } \\
\text { Africa: } \\
15,000 \text { birds }\end{array}$ & 150 birds & 127 & 3 & $\frac{\text { http://wpe.wetlands.org/ }}{\text { view/1531 }}$ \\
\hline
\end{tabular}

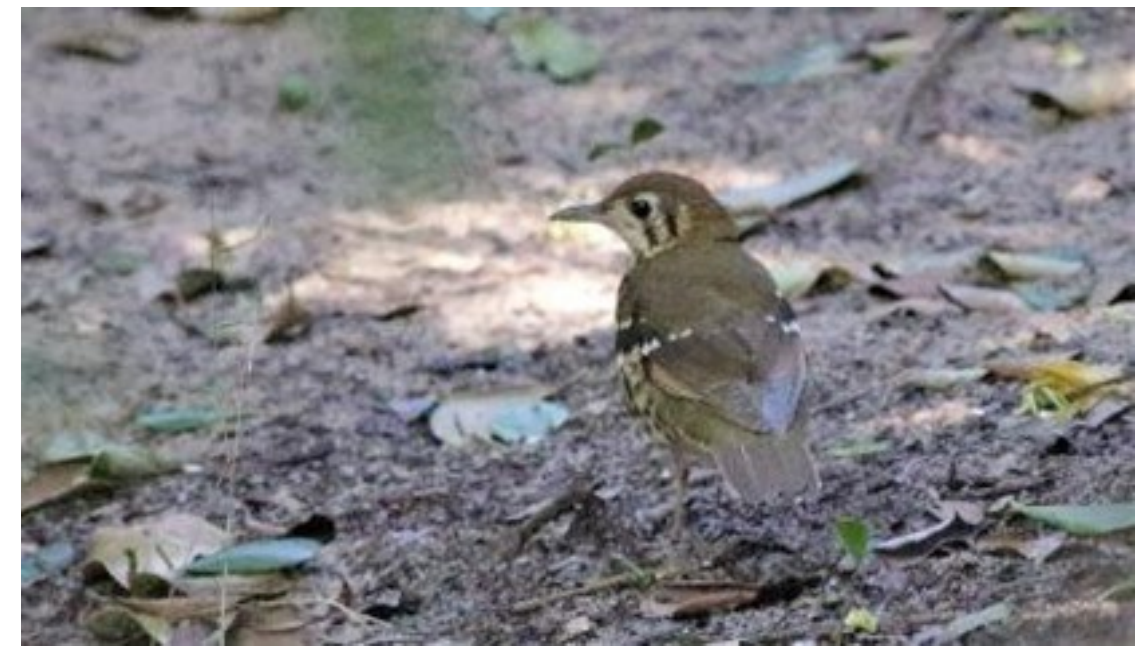

Figure 6. Spotted Ground Thrush Geokichla guttata, Tan 'n' Biki Lodge, Macaneta, Mozambique, 11 Sep 2018. This Endangered species migrates from South Africa to winter in Mozambican coastal forests, probably in significant numbers. Photo: G. Allport. 
Table 4. Maximum counts of all waterbird species recorded at Macaneta, Mozambique Oct 2016-Jun 2020.

\begin{tabular}{|c|c|c|c|}
\hline Species & Max. count & Species & Max. count \\
\hline White-faced Duck & 2,000 & Great Snipe & 1 \\
\hline Fulvous Duck & 500 & African Snipe & 11 \\
\hline Knob-billed Duck & 1 & Common Sandpiper & 10 \\
\hline Egyptian Goose & 4 & Common Greenshank & 35 \\
\hline Spur-winged Goose & 60 & Marsh Sandpiper & 8 \\
\hline Blue-billed Teal & 50 & Wood Sandpiper & 300 \\
\hline Yellow-billed Duck & 8 & Small Buttonquail & 2 \\
\hline Red-billed Teal & 25 & Temminck's Courser & 1 \\
\hline Southern Pochard & 3 & Collared Pratincole & 450 \\
\hline Greater Flamingo & 40 & Grey-headed Gul & 42 \\
\hline Lesser Flamingo & 63 & Kelp Gull & 1 \\
\hline Little Grebe & 1 & Sooty Tern & 200 \\
\hline Red-chested Flufftail & 1 & Little Tern & 6 \\
\hline African Rail & 15 & Gull-billed Tern & 1 \\
\hline Corncrake & 1 & Caspian Tern & 2 \\
\hline Spotted Crake & 1 & White-winged Tern & 35 \\
\hline Lesser Moorhen & 3 & Whiskered Tern & 200 \\
\hline Common Moorhen & 25 & Common Tern & 53 \\
\hline Red-knobbed Coot & 1 & Swift Tern & 20 \\
\hline African Swamphen & 45 & Sandwich Tern & 40 \\
\hline Black Crake & 15 & Lesser-crested Tern & 200 \\
\hline Baillon's Crake & 10 & African Openbill & 130 \\
\hline Water Thick-knee & 3 & Woolly-necked Stork & 20 \\
\hline Black-winged Stilt & 35 & Yellow-billed Stork & 60 \\
\hline Pied Avocet & 12 & African Darter & 1 \\
\hline Grey Plover & 4 & Reed Cormorant & 275 \\
\hline Long-toed Lapwing & 2 & White-breasted Cormorant & 400 \\
\hline Blacksmith Lapwing & 20 & Cape Cormorant & 20 \\
\hline Senegal Lapwing & 4 & Great White Pelican & 130 \\
\hline Crowned Lapwing & 1 & Pink-backed Pelican & 80 \\
\hline Wattled Lapwing & 40 & Hamerkop & 15 \\
\hline Lesser Sand-Plover & 1 & Little Bittern & 20 \\
\hline Kittlitz's Plover & 100 & Grey Heron & 75 \\
\hline Common Ringed Plover & 500 & Black-headed Heron & 25 \\
\hline Three-banded Plover & 35 & Goliath Heron & 1 \\
\hline White-fronted Plover & 10 & Purple Heron & 90 \\
\hline Greater Painted-Snipe & 1 & Great Egret & 400 \\
\hline Lesser Jacana & 1 & Little Egret & 250 \\
\hline African Jacana & 2 & Intermediate Egret & 400 \\
\hline Eurasian Whimbrel & 30 & Black Heron & 200 \\
\hline Eurasian Curlew & 1 & Cattle Egret & 350 \\
\hline Ruddy Turnstone & 18 & Squacco Heron & 75 \\
\hline Ruff & 300 & Rufous-bellied Heron & 1 \\
\hline Sharp-tailed Sandpiper & 2 & Green-backed Heron & 1 \\
\hline Curlew Sandpiper & 120 & Black-crowned Night Heron & 75 \\
\hline Sanderling & 10 & Glossy Ibis & 800 \\
\hline Little Stint & 140 & Sacred Ibis & 185 \\
\hline White-rumped Sandpiper & 1 & Hadeda Ibis & 14 \\
\hline Pectoral Sandpiper & 2 & African Spoonbill & 75 \\
\hline
\end{tabular}




\section{Notable records}

Macaneta yielded a remarkable series of notable bird records in a short period of time (Table 5.). This is likely a result of a combination of the unique position of the site at the head of Maputo Bay, favourably geographically positioned to draw in passage migratory birds, with a diversity of habitats in a restricted area, in tandem with good observer coverage by many skilled birders able to enjoy good bird viewing con- ditions. There were also remarkable birding coincidences, such as a flock of Sharp-tailed and Pectoral sandpipers (Allport 2018a, b) and three species of rare Hirundine present together 19 May 2019 (Allport et al. 2021) - these exceptional rarities were occupying a short section of telephone wire with no similar records at this well-watched locality before or since. Co-occurrence of this sort is hard to explain (Allport et al. 2021).

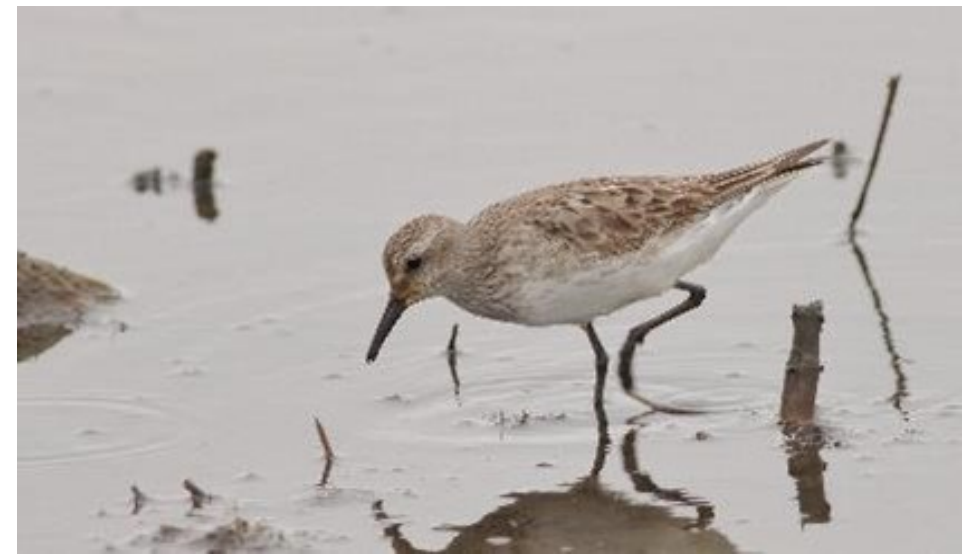

Figure 7. White-rumped Sandpiper Calidris fuscicollis, Macaneta, Mozambique, Sep 2018. First record for Mozambique. Photo: G. Allport.

Table 5. Notable bird records from Macaneta, Oct 2016-Jul 2020. See annotated checklist for details of each species.

\begin{tabular}{|c|c|c|}
\hline Species & Status & Dates \\
\hline Sharp-tailed Sandpiper Calidris acuminata & $1^{\text {st }}$ record for continental Africa & $\begin{array}{l}\text { Feb-Apr 2018, Feb-Apr 2019, Oct 2019- } \\
\text { Feb } 2020\end{array}$ \\
\hline Pectoral Sandpiper Calidris melanotos & $2^{\text {nd }}-6^{\text {th }}$ records for Moz (of 7 ) & $\begin{array}{l}\text { Feb-Mar 2018, Oct 2018-Mar 2019, Oct } \\
2019\end{array}$ \\
\hline White-rumped Sandpiper Calidris fuscicollis & $1^{\text {st }}$ record for Moz, $32^{\text {nd }}$ recordfor Africa & Sep 2019 \\
\hline Pearl-breasted Swallow Hirundo dimidiata & $1^{\text {st }}$ record for Moz & May 2019 \\
\hline Gull-billed Tern Gelochelidon nilotica & $8^{\text {th }}$ record for Moz & Jan 2019 \\
\hline White-throated Swallow Hirundo albigularis & $7^{\text {th }}-9^{\text {th }}$ records for $\mathrm{Moz}$ & May 2019 \\
\hline Pallid Harrier Circus pallidus & $1^{\text {st }}$ record in sthn Moz & Dec 2018 \\
\hline Spotted Crake Porzana porzana & $1^{\text {st }}$ records in sthn Moz & Jan-Mar 2018 \\
\hline Speckled Pigeon Columba guinea & $1^{\text {st }}$ documented record in sthn Moz & Feb 2020 \\
\hline Spotted Ground Thrush Geokichla guttata & $5^{\text {th }}$ record for sthn Moz & Sept 2018 \\
\hline Great Snipe Gallinago media & $1^{\text {st }}$ recent record for sthn Moz & Mar 2019 \\
\hline Montagu's Harrier Circus pygargus & $1^{\text {st }}$ recent records in sthn Moz & Oct 2017 \\
\hline Cape Cormorant Phalocrocorax capensis & Most northerly records (Cape endemic) & Aug 2019 \\
\hline Mascarene Martin Phedina borbonica & Most southerly record in Moz & May 2019 \\
\hline Corn Crake Crex crex & Most southerly record in Moz & Dec 2018 \\
\hline Long-toed Lapwing Vanellus crassirostris & Most southerly record in Moz & Feb 2018, Mar 2019 \\
\hline Woodwards' Batis Batis fratrum & Endemic to forests of Maputaland hotspot & \\
\hline Rudd's Apalis Apalis ruddi & Endemic to forests of Maputaland hotspot & \\
\hline
\end{tabular}




\section{Visitors to see Sharp-tailed Sandpiper}

During the first period when the Sharp-tailed Sandpiper was present (Feb-Apr 2018) international visitors (at least 68) coming to view the bird stayed on site at one of three lodges (Tan 'n' Biki, Lugar do Mar or Jays Beach Lodge) for a total of 254 bed nights at c. US\$50 per person per night for accommodation, food and drinks, thus bringing approximately US $\$ 12,000$ into the local economy. This was one of three periods when the Sharp-tailed Sandpiper was present (see Table 5) but data were only gathered in the first period reported above.

\section{Annotated checklist of selected species}

Accounts of all key species referred to above are given below, and in addition any species where the observations at Macaneta have significantly updated the status in Sul do Save or more widely are also covered. The region of southern Mozambique follows the defined ornithological subregion south of the Zambezi river here (Hockey et al. 2005), and Sul do Save similarly the area south of the Save River (after Parker 1999).

The status of each species is reviewed in the light of background from three major references; Clancey (1996), Parker (1999) and Hockey et al. (2005). Sightings around Maputo 2010-2019 by GA are referred to as GA pers. obs. Observers are indicated by their initials and links to specific eBird checklists are given where these contain additional comments, photos or sound recordings.

Contributors were: Jude Allport (JA), Barnaby Briggs (BB), Manuel Costeira da Rocha (MCdR), Chris Curtis (CC), Olivier Hamerlynck (OH), Trevor Hardaker (TH), Robert LindsayRae (RLR), Etienne Marais (EM), Morris Ngwenyema (MN), Justin Rhys Nicolau, (JRN) Niall Perrins (NP), David Pitzalis (DP), Lynette Knott Rudman (LKR), Alan Bedford-Shaw (ABS), Dominic Paul Rollinson (DPR), Etienne Marais (EM) and Emidio Sumbane (ES).

\section{Little Grebe Tachybaptus ruficollis}

Not uncommon around Maputo (GA pers. obs.) so only one record at Macaneta $24 \mathrm{Dec} 2017$ (GA) is surprising.

\section{Cape Gannet Morus capensis}

Globally Threatened, Endangered

Regular offshore in Maputo Bay Jun-Oct (GA pers. obs.) but uncommon offshore at Macaneta. Four records Jun-Oct include a group of 30 feeding over tuna 11 Aug 2019 (MCdR).

\section{White-breasted Cormorant Phalacrocorax carbo lucidus}

Fairly common in open water habitat around Maputo (GA pers. obs.). Small numbers feed at Macaneta but large numbers arrive to roost on Eucalyptus trees along the river banks in the afternoon. Recorded 127/172 eBird site checklists with internationally important numbers above Ramsar $1 \%$ threshold of 150 birds for the subspecies on five dates (counts 400, 250, 175, 170, 160, Dec-Mar); birds flighting from Maputo Bay possibly drawn from a significant area.

\section{Cape Cormorant $\boldsymbol{P}$. capensis}

Globally threatened, Endangered

This endemic seabird, breeding along the Angolan, Namibi- an and Cape coasts of South Africa, feeds communally on dense shoals of marine forage fish and is known to track the Sardine run northwards along the Indian Ocean coast, JunNov (Hockey et al. 2005). Up to 300 birds have been seen at Inhaca (de Boer and Bento 1999) and in Maputo Bay (Brooke et al. 1981) with three recent records (GA pers. obs.). A group of 20 resting on the beach and close inshore at Macaneta 18 Aug 2019 (JH; https://ebird.org/checklist/ S59080139) shows the continued importance this area for the species.

\section{Black Egret Egretta ardesiaca}

This attractive heron is quite widespread in southern Africa but scarce in Mozambique (Hockey et al. 2005), with a population estimate of $<50$ birds (Parker 1999). Present at Macaneta mid-Nov to July. A total of 110 records peaking at a maximum of 200 birds per day.

\section{Rufous-bellied Heron Ardeola rufiventris}

Scattered records over littoral of Sul do Save (C, four records at three sites, Parker 1999). Not regular at Macaneta with four records Feb-July.

\section{Little Bittern Ixobrychus minutus}

Uncommon in southern Africa (Hockey et al. 2005). Seven records at six sites est. $<100$ birds in littoral of Sul do Save by Parker (1999). 82 records at Macaneta Dec-May, peak in Jan with up to 20 birds per day. Palearctic migrant birds may have been present but up to eight calling birds and recently fledged young found, confirming the Afrotropical subspecies I. $m$. payesii breeding at Macaneta.

\section{Goliath Heron Ardea goliath}

Described as numerous by Clancey (1996) but uncommon by Parker (1999) who estimated 100 birds in Sul do Save. Seven records at Macaneta but probably only two birds involved.

\section{Honey buzzard sp. Pernis sp.}

A juvenile Honey buzzard sp. photographed as it soared over the western part of the site on 25 Mar 2018 (GA; Fig. 8) divided expert opinion as to whether it was a hybrid between the two species of Pernis or a 'pure' Crested Honey Buzzard Pernis ptilorhynchus; if the latter this would have been the first record for southern Africa.

\section{Montagu's Harrier Circus pygargus}

A rare Palearctic migrant in Sul do Save (Clancey 1996, Parker 1999). Two records at Macaneta 3 Dec 2016 (SABAP) and 10 Dec 2017 (BB; https://ebird.org/checklist/ S41009097).

\section{Pallid Harrier Circus macrourus}

Not previously recorded in Sul do Save (Clancey 1996, Parker 1999) but reported around Beira (Grant and Haagner per C); not found by Parker (1999). A fine male bird at 'The Sharpie Spot' 22 Dec 2019 (NP, LKR; Fig. 9) was thus the first record for Sul do Save.

\section{Peregrine Falcon Falco peregrinus}

Considered marginal by Clancey (1996), and rare by Parker (1999). 1-2 pairs of subspecies minor found resident and breeding in Maputo, with one record of Palearctic migrant 
subspecies calidus (GA pers obs.). Five records at Macaneta Sep-Mar at Macaneta were all judged to be of the race calidus probably on passage.

\section{Eurasian Hobby Falco Subbuteo}

Not recorded in Sul do Save by Clancey (1996), 7 records by Parker (1999) and not recorded around Maputo (GA pers. obs.). A single bird at Macaneta 18 Jan 2020 (OH) was thus a notable record.

\section{Red-necked Spurfowl Pternistis afer}

Not recorded around Maputo (GA pers. obs.), but resident and regularly recorded at Macaneta throughout the year in the areas of cropland on the damp sandy areas immediately landward of the dunes. Easily located by its call.

\section{African Rail Rallus caerulescens}

Reported as widely distributed in the littoral by Clancey (1996) but with few records. Seven records by Parker (1999) in Sul do Save and very uncommon around Maputo (GA pers. ob.). Regular Jan-Jun with up to 15 birds at Macaneta. Most records were of calling birds deep in the reed beds and may be present all year but silent in the dry season.

\section{Corn Crake Crex crex}

Few records of this Palearctic migrant in Sul do Save (C, one record by Parker 1999) but 'rarity' likely a result of its secretive habits. A single bird which flew from Salicornia marsh and across the road, nearly hit the observer in the face, 8 Dec 2018 (GA; https://ebird.org/checklist/ $\underline{\mathrm{S} 50508108)}$

\section{Spotted Crake Porzana porzana}

Only one historical record of this secretive Palearctic migrant in southern Mozambique by Haagner (per Clancey 1996) who reported it as "fairly common" near Beira. Not recorded by Parker (1999).

Three records from the site Jan-Mar 2018 are thus new to Sul do Save and suggest it is regular in small numbers. All were sighted in the easternmost part of the Central Basin where the main reed bed extends across the road.

This locality, known as the 'rail crossing spot', afforded good views of rallids as they travelled on foot across the low lying section of track, especially at dawn and dusk.

\section{Allen's Gallinule Porphyrula alleni}

Few records of this Afrotropical migrant in Sul do Save (Clancey 1996, 2 records by Parker 1999) but, again, fairly secretive. Nine records at Macaneta Feb-May (Fig. 10). Identification mostly in flight whilst moving between reed beds.

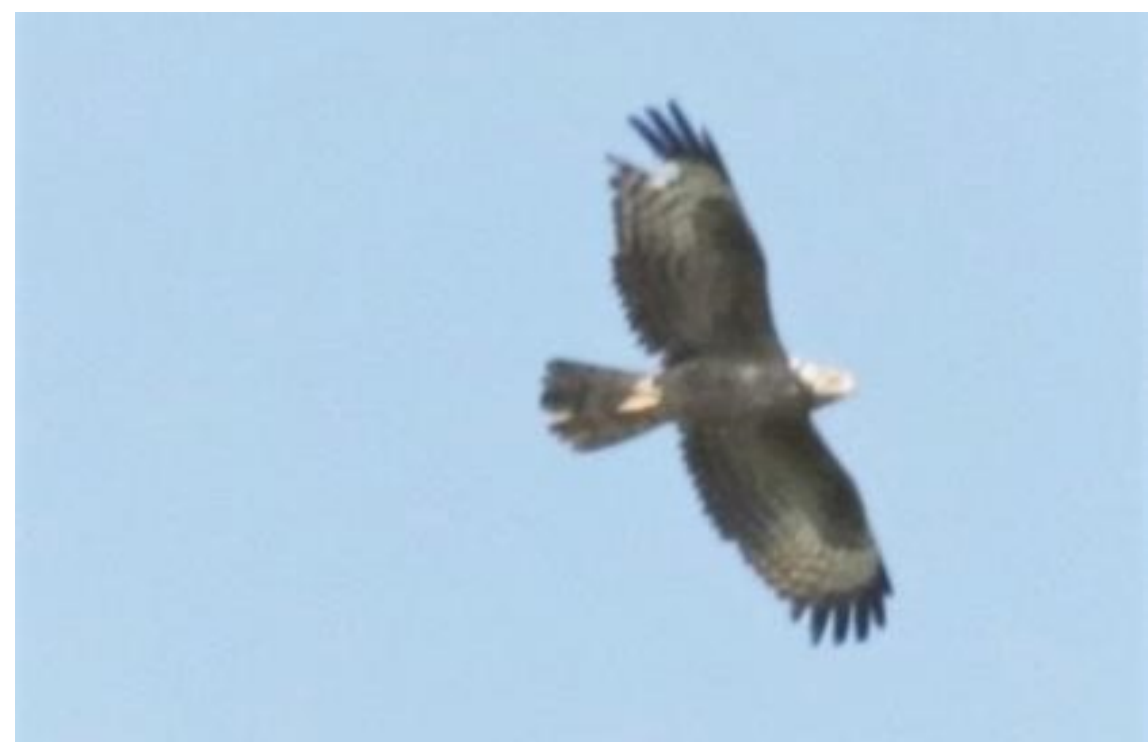

Figure 8. Crested Honey Buzzard Pernis ptilorhynchus or hybrid x Eurasian Honey Buzzard P. apivorus, Macaneta, Mozambique, 25 Mar 2018. Note heavier eagle-like build and broader wings than typical apivorus with six clear primary 'fingers and densely-barred secondaries (5 bars). Photo: G. Allport.

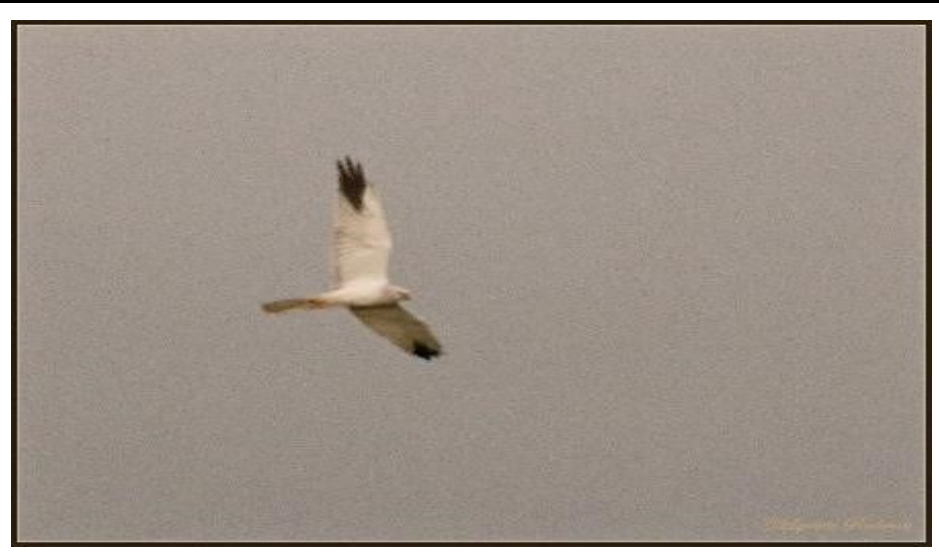

Figure 9. Pallid Harrier Circus macrourus, Macaneta, Mozambique 22 Dec 2019. First record for Sul do Save. Photo: L. Rudman. 


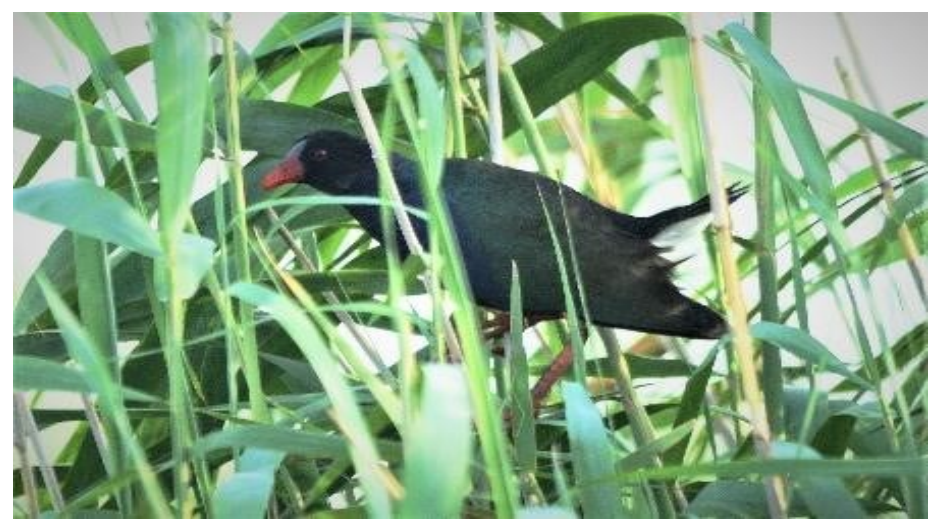

Figure 10. Allen's Gallinule Porphyrula alleni, Macaneta, 4 Feb 2018, at the 'rail crossing' spot (see text). Photo: M. Costeira da Rocha.

\section{Lesser Moorhen Gallinula angulate}

One record by Parker (1999) and up to six birds at one wetland near Maputo 25 Feb 2018 (GA pers. obs.). Five records Feb-May at Macaneta, all from flooded tall grassland were mostly located by a pre-dawn repetitive clucking call (apparently undescribed https://www.xenocanto.org/403523).

\section{Baillon's Crake Zapornia pusilla}

Reported from two localities by Clancey (1996) and not found by Parker (1999), but highly secretive and best located by call pre-dawn (Lekuona et al. 2017). Twenty-nine records of 1-7 birds calling from freshwater-flooded vegetation along roadsides pre-dawn, Jan-Mar. A notable late influx of ten calling birds 18 May 2019. Often responded to playback of recorded call.

\section{Black-bellied Bustard Eupodotis melanogaster}

Formerly common breeder in southern Mozambique in the austral summer (Clancey 1996), but declining (Parker 1999) and very uncommon more recently around Maputo (GA pers. obs.). 1-3 birds regularly June-October in drier grasslands at Macaneta with no evidence of breeding.

\section{Lesser Sand Plover Charadrius mongolus}

Rare in Sul do Save, two records by Clancey (1996) and three locations by $P$, but found regularly in small numbers (up to 15 birds) in Maputo Bay (GA pers. obs). Two records at Macaneta 31 Oct 2015, 6 Jan 2019 (GA).

\section{Long-toed Lapwing Vanellus crassirostris}

One historical record of this Afrotropical species from Incomati River floodplain (Clancey 1996) and more recently the San Sebastian Peninsula (Parker 1999, Read et al. 2014). Two birds which stayed briefly in the Salicornia marsh area 21 Mar 2019 (SO; https://ebird.org/checklist/ S54236107) are the only recent records in the Maputo area.

\section{Curlew Sandpiper Calidris ferruginea}

Globally Near-threatened

Common Palearctic migrant on Mozambique coast and inland wetlands (Clancey 1996, Parker 1999). Present at Macaneta Aug-May mostly in saline/ brackish areas in small flocks of 5-10 birds normally totalling $30-50$ birds with maximum 120.

\section{White-rumped Sandpiper Calidris fuscicollis}

Rare in Africa (37 records, Allport 2020) one bird at "The Sharpie Spot" 22-25 Sep 2018 (GA: https://ebird.org/ checklist/S48797255, Fig. 7) was new to Mozambique.

\section{Sharp-tailed Sandpiper C. acuminate}

This vagrant, breeding in north-east Asia, was new to continental Africa (Allport 2018a) and is the 'signature bird' of Macaneta (Fig.1). First seen on 4 Feb 2018 (BB, GA, MCdR) but not identified until 18 Feb 2018 (GA: https:// ebird.org/checklist/S43105779), immediately attracting a significant influx of birders to the site (see above). Not seen again until 3 Mar when joined by a second bird (JRN) on the spring tide (see Allport 2018b for account).

A pattern of occurrence on spring tides in the Salicornia marsh ("The Sharpie Spot", Fig. 3) emerged with birds being seen every two weeks on new and full moon tides until 16 Apr 2016. Presumably one of the same birds was re-found at the same spot on 21 Feb 2019 (GA) and was again recorded on spring tides until $20 \mathrm{Apr} 2019$, and then returned 16 Oct $2019(\mathrm{OH})$ and last seen 13 Feb 2020 $(\mathrm{JH})$. All birds seen were adults and examination of images suggests only two birds were involved.

\section{Pectoral Sandpiper C. melanotos}

A rare vagrant to southern Africa from north-east Asia and the Nearctic (Hockey et al. 2005), first recorded in Mozambique in Jan 2017 (Allport 2018c). Confusingly similar to Sharp-tailed Sandpiper (STS) and first found at Macaneta 20 Feb 2016, at 'The Sharpie Spot' two days after the first STS, and then two joined the two STSs on 34 Mar forming a small flock of four birds (GA, BB, TH, RLR; see Allport 2018b for account). 1-2 Pectoral Sandpipers on spring tides thence to 31 Mar 2018.

One 10 Nov 2018 (GA) to 23 Jan 2019 and two (EM) 6-21 Mar 2019. One 29 Sep $2019(\mathrm{JH})$ but no further records despite regular observations to Feb 2020. All birds seen were adults and may have been only two birds involved.

\section{Great Snipe Gallinago media}

Globally Near-threatened

Rare Palearctic migrant to freshwater marshes of the Mozambique littoral in small numbers, with one record at Marracuene (Clancey 1996). Not recorded by Parker 1999. One found feeding on main track pre-dawn 21 Mar 


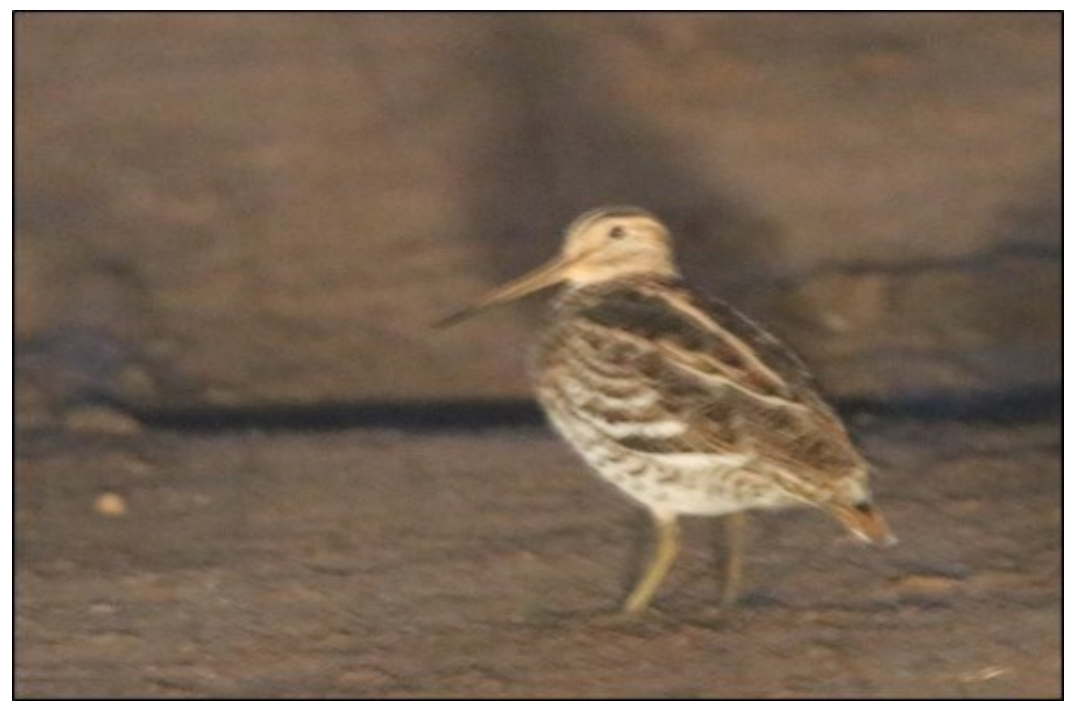

Figure 11. Great Snipe Gallinago media, Macaneta, Mozambique, 21 Mar 2019, on road pre-dawn. Identified by broad white tips to the greater, median and lesser wing coverts. First recent record in Sul do Save. Photo: G. Allport.

2019 (GA; Fig. 11). A much sought-after species by birders, this encounter led to specific searches but no further sightings.

\section{African Snipe G. nigripennis}

Uncommon breeding resident in the southern Mozambique littoral (Clancey 1996, Parker 1999). At Macaneta from late Jan and breeding in small numbers - minimum c. 10 pairs but possibly more - starting drumming display flights in lateFeb and continuing into May.

\section{Eurasian Curlew Numenius arquata}

\section{Globally Near-threatened}

Noted as rare on coasts by Clancey (1996) and Parker (1999), and only found at one locality around Maputo (1-8 birds roosting at Salinas Zacharias, GA pers. obs.). A single record at Macaneta 11 Sep 2018 (BB, GA).

\section{Common Whimbrel N. phaeopus}

Common on mudflats of Maputo Bay. 10-30 birds regularly at Macaneta Aug-May. A satellite-tagged Steppe Whimbrel N. p. alboaxillaris was tracked to Praia do Macaneta in a period of neap tides in Feb-Mar 2016 (Allport 2017, Allport et al. 2018).

\section{Collared Pratincole Glareola pratincola}

Fairly common breeding resident of the littoral (Clancey 1996, Parker 1999). Resident at Macaneta. Around 30 pairs bred on drier grasslands, especially winter-burned areas in the Central Basin, commencing in late Oct-early Nov and fledging by end of Jan, at which point numbers built significantly in the same area with a roost gathering reaching 300 450 birds by mid-Feb.

\section{Gull-billed Tern Gelochelidon nilotica}

A single bird seen moving downriver 6 Jan 2019 (GA: https://ebird.org/checklist/S51374094) was the sixth record in Mozambique (Allport 2018d). A bird in similar state of moult, almost certainly the same bird, was seen in KwaZulu-
Natal on 9 Jan 2019 (J. Boyce pers. comm. https://ebird.org/ checklist/S51924520).

\section{Sooty Tern Onychoprion fuscatus}

Regular offshore in southern Mozambique waters (Allport 2018d) but rare inshore (Clancey 1996, Parker 1999) and only one record around Maputo (GA pers. obs.). A flock of 200 seen along the beach at Macaneta 22 May 2013 (EM) was therefore a notable record.

\section{Whiskered Tern Chlidonias hybrida delalandii}

Restricted distribution in Sul do Save littoral, local in small numbers (Clancey 1996, Parker 1999). Fairly common in marshy habitat around Maputo breeding in small colonies 310 pairs (GA pers. obs.). Present at Macaneta most of the year, only absent late Aug-Sep.

Recorded 141/172 eBird checklists with internationally important numbers above Ramsar $1 \%$ threshold of 85 birds for the regional population of the subspecies on five dates (counts 200, 140,120,135, 85; Dec-Mar). No evidence of breeding at Macaneta.

\section{White-winged Tern Chlidonias leucopterus}

Reported as fairly common in wetlands of Sul do Save (Clancey 1996, Parker 1999) but no recent records around Maputo (GA pers. obs.). Not recorded at Macaneta until a single 21 Mar 2019 (SO) and then a marked passage late Feb-early Mar 2020 peaking at 35 birds (EM) feeding in flocks over the flooded grasslands.

\section{Speckled Pigeon Columba guinea}

Common in similar habitats at sea level in Kwa-Zulu Natal (Hockey et al. 2005), so the almost complete absence of this species in Mozambique is surprising (Clancey 1996). The first record in Mozambique was by Parker (2005) who found it uncommon in mountainous areas in central Mozambique near the border with Zimbabwe. A single bird seen well feeding in the grounds of Tan 'n' Biki Lodge, 8 Feb 2020 when all the key features were noted by several observers 


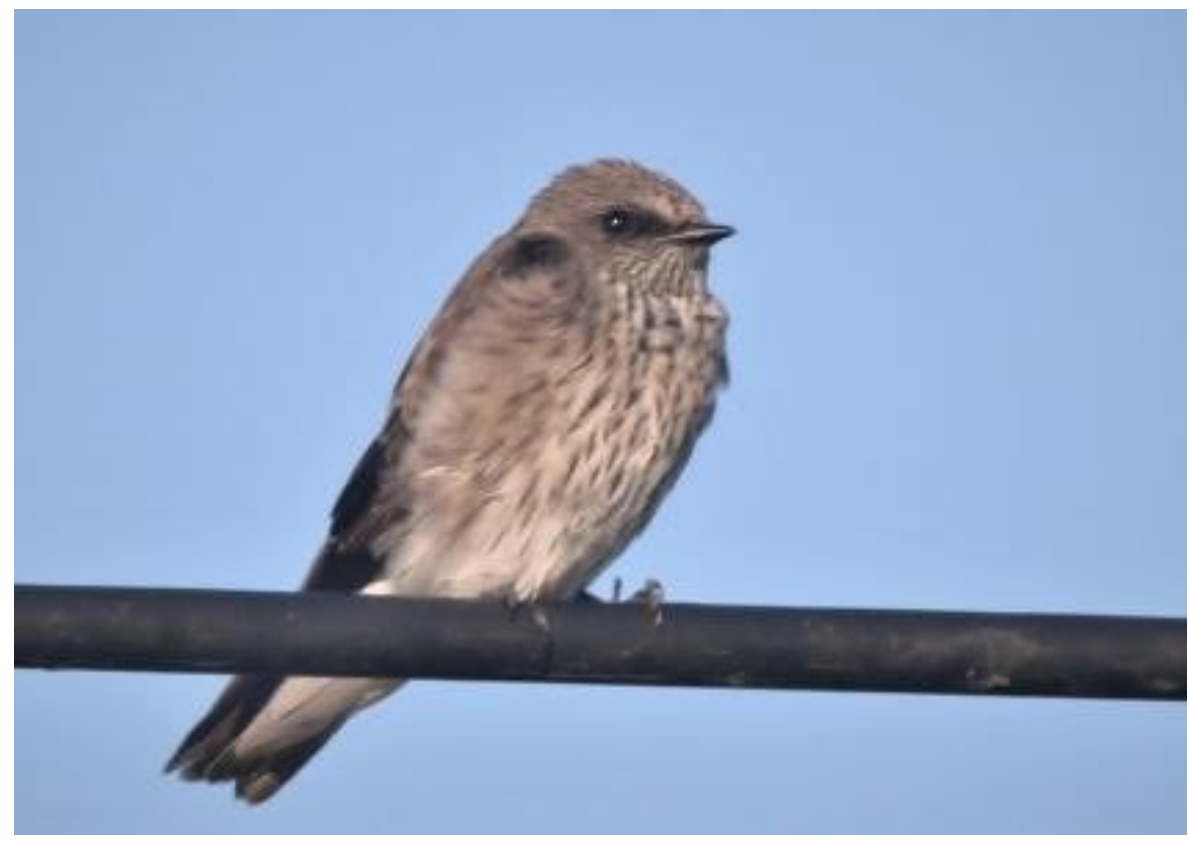

Figure 12. Mascarene Martin Phedina borbonica, Macaneta, Mozambique, 18 May 2020. Note this bird shows streaking on the undertail coverts, a feature given for Brazza's Martin P. brazzae, a possible vagrant to the sub-region (Sinclair and Ryan 2010), but was excluded by larger size in comparison with nearby Lesser Striped Swallows Cecropis abysinnica and call. Photo: G. Allport.

(EM et al.), was thus the first documented record in Sul do Save.

\section{Black Coucal Centropus bengalensis}

Uncommon Afrotropical migrant (Clancey 1996, Parker 1999), Oct-Apr breeding, first found in inland wetlands of Sul do Save by Parker (1999). 1-3 birds heard at Macaneta giving distinctive song Feb-Apr are the only recent records in the Maputo area.

\section{African Marsh Owl Asio capensis}

Reported as locally not uncommon by Clancey (1996) but very rare (3 records) by Parker (1999), and one record around Maputo (GA pers. obs.). Regular at Macaneta AprSep, mostly singles but up to six birds (ABS). No conclusive evidence of breeding but highly likely with aerial display flights seen on many occasions in the dry season, when this species breeds.

\section{African Palm Swift Cypsiurus parvus}

A widespread and common local resident this species was abundant at Macaneta with up to 700 birds per day. There was, however, a notable diurnal pattern of occurrence with birds absent at dawn then arriving, along with other swift species, from the south-west starting 45-90 minutes later, peaking mid-morning.

\section{Olive Bee-eater Merops superciliosus}

Very locally breeding Sept-May in the Sul do Save littoral with a small population on Inhaca Is. (de Boer and Bento 1999, Parker 1999). Slightly surprisingly only one record around Maputo (GA pers. obs.) and one record from Macaneta, 3 Mar 2018 (BB).

\section{African Grey Hornbill Tockus nasutus}

Restricted to the dry interior and west of Sul do Save (Clancey 1996, Parker 1999). An unusual influx to the Ma- puto area in August 2019 with two birds at Macaneta 8 Sep $2019(\mathrm{JH})$.

\section{Brown-backed Honeybird Prodotiscus regulus}

Very rare in Sul do Save (Clancey 1996, 5 localities Parker 1999). Three records around Maputo (GA pers. obs.).

One at Macaneta 22 Jun 2019 (GA).

\section{Mascarene Martin Phedina borbonica}

Little known uncommon migrant from Madagascar Mar-Oct, mostly in central Mozambique (Parker 2005) but records as far south as Xai-Xai in the littoral (Allport et al. 2021).

A single bird on power lines near the 'Sharpie Spot' 18-19 May 2019 was the southernmost record in Mozambique (Fig. 12).

This bird formed part of a triumvirate of rare hirundine species at Macaneta at that time (see below).

\section{White-throated Swallow Hirundo albigularis}

Rare in upland grasslands of Sul do Save (Allport et al. 2021). An adult and juvenile at Macaneta 19-22 May 2019 $(\mathrm{GA}, \mathrm{OH})$ were notable records in the littoral.

\section{Pearl-breasted Swallow Hirundo dimidiate}

Status in Mozambique unclear (see Allport et al. 2021 for review). An adult on power lines near 'The Sharpie Spot' 19 May 2019 for one day only was the first documented record for Mozambique (OH, Fig. 13).

\section{Red-breasted Swallow Cecropis semirufa}

Rare in Sul do Save (20 records at nine localities by Parker [1999], Allport et al. 2021).

One record of this distinctive species at Macaneta; four, 31 Oct 2015 were prospecting a culvert under the road but breeding was not confirmed (JA, GA, Fig. 14). 


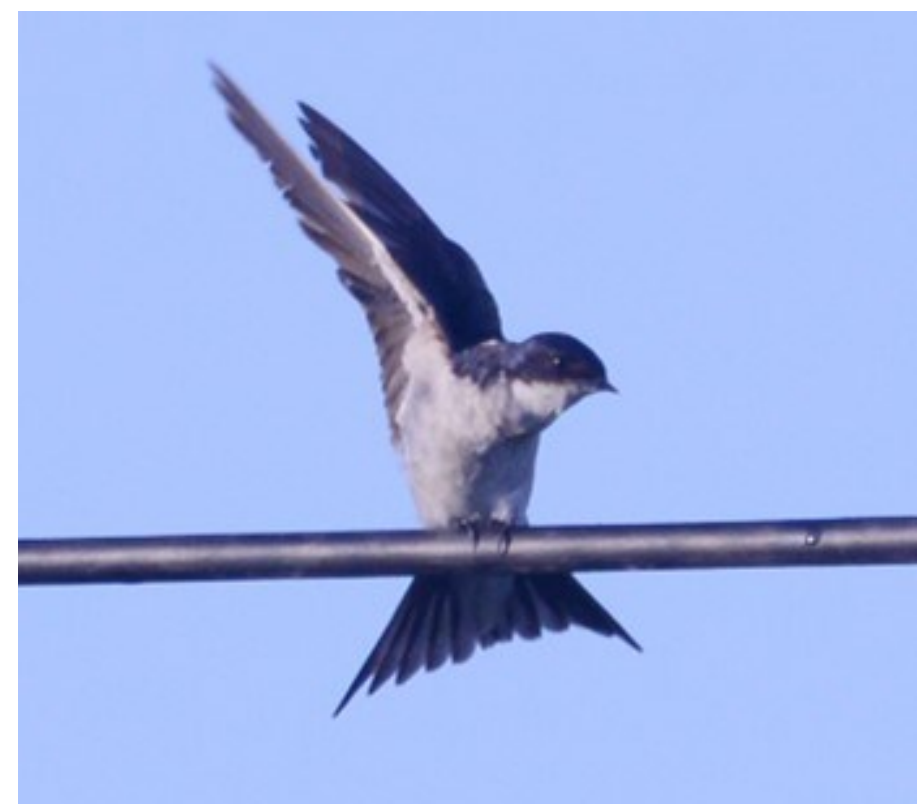

Figure 13. Pearl-breasted Swallow Hirundo dimidiata, Macaneta, Mozambique, 19 May 2019. The first documented record for Mozambique. Photo: O. Hamerlynck.

\section{Spotted Ground Thrush Geokichla guttata}

\section{Globally Threatened, Endangered}

Breeds in highly fragmented small populations in montane forests in Sudan, DR Congo, Tanzania, south Malawi and KwaZulu-Natal and Eastern Cape, South Africa. The latter populations, estimated at $400-800$ pairs, migrate to $\mathrm{KZN}$ coastal forests leaving Mar-May returning Aug-Sep (Hockey et al. 2005). In Mozambique first noted by Parker (2005) reporting single birds seen near Ponta Milibangalala, Maputo Special Reserve, Nov 1999 (J. Culverwell) and Inhaca Island in Apr 2002 (J. Kromer).

Subsequent record further north at Dunes de Dovela in coastal forest Jun-Sep 2017 (TB; https://ebird.org/checklist/ S37464431). One at Macaneta in grounds of Tan ' $n$ ' Biki Lodge 8-23 Sep 2018 (BB; https://ebird.org/checklist/ $\underline{\mathrm{S} 48432545}$, Fig. 6).

It seems very likely that breeding birds from the South African populations migrate to the coastal forest of Mozambique in the austral winter and, bearing in mind the low observer coverage, secretive nature of the bird and extensive habitat, it may be that the numbers involved are significant at population level. However, this species has also been found at both Mt. Namuli (Timberlake et al. 2009) and Mt. Mabu (Timberlake et al. 2012) in northern Mozambique. These birds may be part of the population of the belcheri subspecies, previously only known from southern Malawi, and which are thought to be resident but this is not known for certain. The exact breeding origins of the few birds seen in Mozambican coastal forest therefore remain to be confirmed.

\section{Brown Scrub-Robin Erythropygia signata}

A scarce forest-dependent endemic to the coastal forests of KwaZulu-Natal and the escarpment forests of Limpopo Province, South Africa, with isolated populations in the coastal forests of Mozambique (Hockey et al. 2005). Distribution is discontinuous; present in some forests but not others, so the confirmation of this species at Macaneta in the grounds of Jays Lodge $(\mathrm{OH})$ and Tan' n Biki (GA), further highlights the importance of the thicket forests at Macaneta for endemic species.

\section{Sedge Warbler Acrocephalus schoenobaenus}

Palearctic migrant reported as rare (Clancey 1996, Parker 1999) or sparse (Hockey et al. 2005), in the Mozambique littoral. Forty-six records, up to 35 birds per day at Macaneta, late-Dec to mid-Apr show this to be a more frequent species in the littoral than previously thought.

\section{Rudd's Apalis Apalis ruddi}

Endemic to coastal KwaZulu-Natal, eastern Eswatini, Mozambique and southern Malawi, where found in Acacia woodland and coastal thicket (Clancey 1996, Parker 1999, Hockey et al. 2005). Fairly common resident at Macaneta in coastal thicket and was frequently seen in the grounds of Jays Lodge.

\section{Wing-snapping Cisticola Cisticola ayresi}

Very few records in Mozambique from highland grasslands in the Chimanimani Mountains (Clancey 1996), but also known from the lowlands of KwaZulu-Natal (Hockey et al. 2005). One bird giving the distinctive display flight and call (see Peacock 2012) over grasslands near the river bridge, 10 Nov 2018 (GA) was the first record for Sul do Save.

\section{Woodwards' Batis Batis fratrum}

Near-endemic to the coastal plain forests of South Africa and Mozambique, and at one site in Zimbabwe (Hockey et al. 2005). Uncommon in thicket forest at Macaneta; two records in the grounds of the lodges, Mar 2018 (JRN) and 30 Dec 2019 (DPR). 


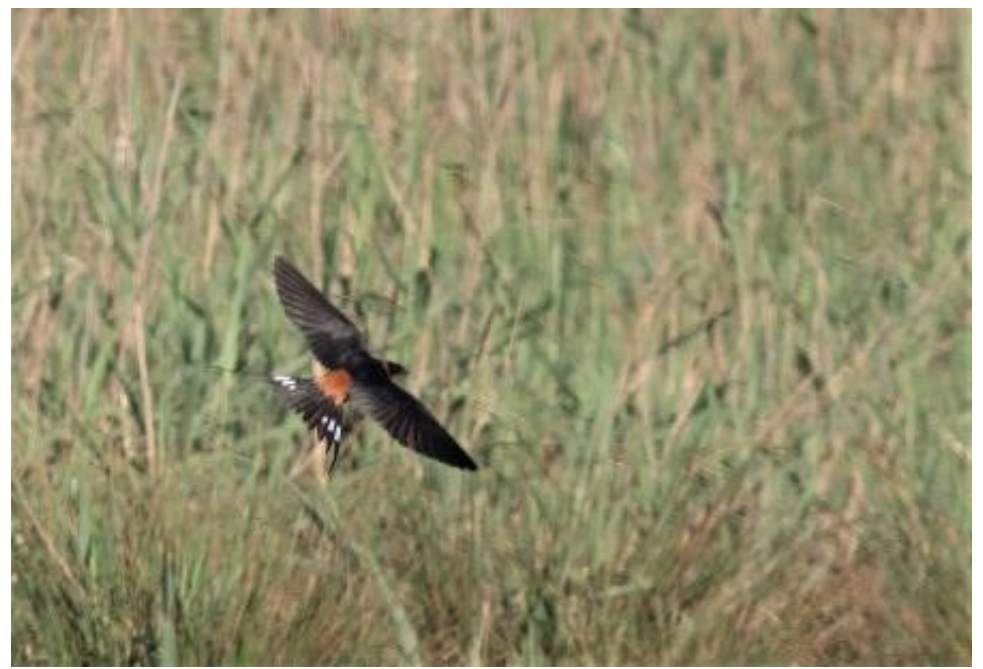

Figure 14. Red-breasted Swallow Cecropis semirufa, Macaneta, Mozambique 15 Oct 2015. Photo: J. Allport.

\section{Black-throated Wattle-eye Platysteira peltate}

This attractive, resident forest bird, popular with birders, is relatively widespread in the southern Africa, but restricted to the coastal plain in southern Mozambique and South Africa (Hockey et al. 2005). Found in intact coastal thicket forest at Macaneta. Most lodges were found to have 1-2 pairs in the grounds, most easily located by their distinctive call.

\section{Cape Wagtail Motacilla capensis}

Widespread breeder in southern Africa but very limited in Mozambique littoral (Parker 1999, Hockey et al. 2005) and thought to be a dry season migrant (Clancey 1996). One pair bred in the grounds of Jays Lodge $(\mathrm{OH})$ but otherwise absent from the site in the austral summer.

A marked influx in mid-April - overlapping by a few days with departing Western Yellow Wagtails - when up to 60 birds roosted in reed beds in the Central Basin and scattered widely in small groups to feed during the day. Remaining at Macaneta until late-Sep.

\section{Western Yellow Wagtail Motacilla flava}

Palearctic migrant found at scattered wetland localities in southern Africa (Hockey et al. 2005). Four records in Sul do Save littoral (Clancey 1996-2, Parker 1999-2). Arrived at Macaneta late October and then regular in small numbers (max. 23) scattered widely but often seen at the 'Sharpie Spot' where a male established a winter territory in 2018/9. Departed early April. Two subspecies recognisable in adult males, flava and thunbergi.

\section{Rosy-throated Longclaw Macronyx ameliae}

This attractive resident of wet grasslands (Fig. 15) has a fragmented range in Africa, with a disjunct population restricted to the littoral of KwaZulu-Natal, South Africa and Sul do Save, Mozambique (Hockey et al. 2005). Noted from Marracuene by Clancey (1996), but only at two localities in the littoral by Parker (1999). Found at three sites around Maputo (GA pers. obs.) always singles or pairs. Resident at Macaneta, found throughout the site but locally mobile at times, keeping to slightly drier areas and avoiding flooded grasslands (Fig. 15). Five pairs were estimated in c. $8 \mathrm{~km}^{2}$ of roadside grasslands (est. 0.625 pairs $\mathrm{km}^{2}$ ) suggesting 23 pairs in the wet grassland area of the site.

\section{Magpie Mannakin Spermestes fringilloides}

Recorded at Marracuene by Clancey (1996) and four localities in the Maputo area by Parker (1999), and five locations by GA (pers. obs). Apparently resident but very unpredictable in local movements. Three records from Macaneta at Tan 'n' Biki (GA) and Jays Lodges $(\mathrm{OH})$.

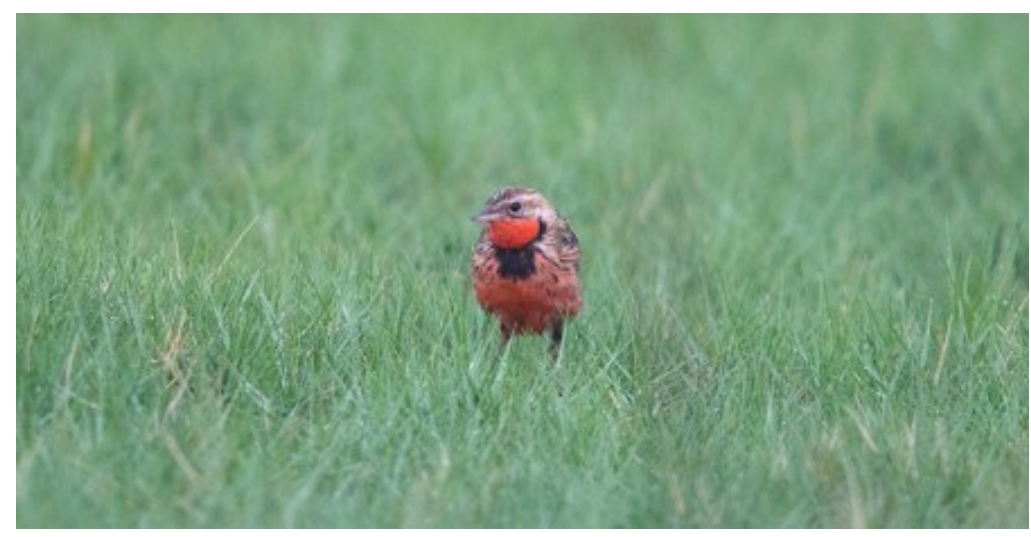

Figure 15. Rosy-throated Longclaw Macronyx ameliae, Macaneta, Mozambique. Photo : C. Curtis. 


\section{Acknowledgments}

Thanks to all those who contributed their bird sightings to the SABAP and eBird databases upon which this study is based and to the named contributors in particular. Special thanks to companions in the field Jude Allport, Barnaby Briggs, Tony Bouw (boat trips), Thomas Brunneau, Manuel Costeira da Rocha, Chris Curtis, Rob Lindsay-Rae, Olivier and Zev Hamerlynck and latterly James Hogg. Justin Rhys Nicolau, Etienne Marais and Trevor Hardaker all helped in finding and promoting 'The Sharpie'. Manuel Costeira da Rocha, Chris Curtis, Olivier Hamerlynck and Lynette Rudman for the use of photographs. Barnaby Briggs, Etienne Marais and Olivier Hamerlynck for comments on the text. Olivier Hamerlynck and Marcos Drumond for important unpublished observations. Thanks go to the staff of the lodges - Tan ' $n$ ' Biki, Lugar do Mar and Jays Beach Lodge - who warmly encouraged visiting birders and helped in many ways. The local people of Macaneta dealt with an invasion of birders with tempered inquisitiveness, patience and the good-natured humour that characterises their country.

\section{References}

Allport GA, Atkinson PW, Carvalho M, Clark NA, Green RE. 2018. Local site use and first northbound migration track of nonbreeding Steppe Whimbrel Numenius phaeopus alboaxillaris (Lowe 1921). Wader Study 125 (3): 219-227 DOI:10.18194/ ws.00126 (pay-walled) https://www.researchgate.net/ publication/330657425 (public).

Allport, G. 2017. Steppe Whimbrels Numenius phaeopus alboaxillaris at Maputo, Mozambique, in February-March 2016, with a review of the status of the taxon. Bulletin of the African Bird Club 24: 27-37. https://www.researchgate.net/ publication/310134556.

Allport G. 2018a. First records of Sharp-tailed Sandpiper Calidris acuminata for Mozambique and continental Africa, and additional records of Pectoral Sandpiper C. melanotos in Mozambique, with comments on identification and patterns of occurrence. Bulletin of the British Ornithologists' Club 138(4): 307317 https://doi.org/10.25226/bboc.v138i4.2018.a3.

Allport G. 2018b. Double takes: finding the Sharp-tailed Sandpiper. African Birdlife 6(4): 22-23 https://www.researchgate.net/ publication/326683768.

Allport G. 2018c. First record of Pectoral Sandpiper Calidris melanotos for Mozambique. Bulletin of the African Bird Club 25(1): 73 -74 https://www.researchgate.net/publication/323699840.

Allport G. 2018d. Notable recent records of terns, gulls and skuas in southern Mozambique including the first country records of Black Tern Chlidonias niger. Bulletin of the British Ornithologists' Club 138(2): 101-116 https://doi.org/10.25226/ bboc.v138i2.2018.a5.

Allport G. 2020. First record of White-rumped Sandpiper Calidris fuscicollis for Mozambique. Bulletin of the African Bird Club 27(2): 240-245 https://www.researchgate.net/ publication/344160718.

Allport G, Del D, Hamerlynck O, Hamerlynck Z. 2021. Update on status and records of Blue Swallow Hirundo atrocaerulea and other hirundines from Mozambique. Bulletin of the British Ornithologists' Club 141(2): 142-155 https://doi.org/10.25226/ bboc.v141i2.2021.a5.

Banks A, Best P, Gullan A, Guissamulo A, Cockcroft V, Findlay K. 2011. Recent sightings of southern right whales in Mozambique. In: Paper SC/S11/RW17 presented to the IWC Southern Right Whale Assessment Workshop 21 (2011).

Bento C, Rufino R 2000. Numbers of waders at two sites in Mozambique, April 1999. International Wader Study Group Bulletin 92: 21-24.
Brooke RK, Cooper J, Sinclair JC. 1981. Additional records of seabirds on the coast of southern Mozambique. Cormorant 9: 3040 .

Burrows JE, Burrows SM, Lotter MC, Schmidt E. 2018. Trees and shrubs of Mozambique. Noordhoek, Cape Town: Publishing Print Matters.

Clancey PA. 1996. The birds of southern Mozambique. Westville, Durban: African Bird Book Publishing.

de Boer WF. 2002. The shorebird community structure at an inter tidal mudflat in southern Mozambique. Ardea 90(1): 81-92.

De Boer WF, Bento C. 1999. The Birds of Inhaca Island, Mozambique. Mondi BLSA Guide No. 22. Johannesburg, South Africa: BirdLife South Africa.

De Boer WF, Parker V. 2000. Birds of the Maputo Special Reserve, Mozambique. Bright Continent Guide \# 2. Cape Town: Avian Demography Unit.

DHI undated. Carving a new path to the sea; using detailed coastal analysis to determine riverbank and coastal erosion. DHI Case Story. https://www.dhigroup.com/global/references/emea/ overview/carving-a-new-path-to-the-sea.

Dutton TP. 1987. A qualitative survey of the wetlands of Moçambique. In: Milstein P le S, Middleton E (eds). Partial Proceedings of the Gamebird Symposium, pp 9-11. South African Journal of Wildlife Research Supplement 1.

Gonzalez R, Serraventosa V. 1999. Mocambique e o protocolo dos rios partilhados da SADC - Constatacoes, questoes e recomendacoes. DNA, comunicacao interna, Maputo.

Hoguane AM. 2002. Salt intrusion in Incomati river. Proceedings of the II-national conference on integrated coastal zone management. Maputo, 27-29 September 2000. CDS-ZC/MICOA, SECAM/UEM, $127 \mathrm{p}$.

Hoguane AM, Antonio MHP. 2016. The Hydrodynamics of the Incomati Estuary - An Alternative Approach to Estimate the Minimum Environmental Flow. In: S. Diop et al (eds.). Estuaries: A Lifeline of Ecosystem Services in the Western Indian Ocean, Estuaries of the World. DOI 10.1007/978-3-319-25370-1_18.

Karlsson C, Liljedahl J. 2015. Coastal evolution at Macaneta Spit, Mozambique; an analysis of longshore and cross-shore processes. Master thesis, University of Lund, Sweden.

Koehler P, Koehler U. 1996. The Bazaruto Archipelago, Mozambique, a site of potential international importance for Palaearctic waterbirds. Ostrich 67(3\&4): 165-167.

Lekuona JM, Artázcoz A, Remón JL, Muñoz JD. 2017. Census, phenology and habitat choice of Baillon's Crakes Zapornia pusilla in Navarre (N Spain). Revista Catalana d'Ornitologia 33:1-9 http://www.ornitologia.org/mm/file/2017 01.pdf.

Milstein P le S. 1984. A waterfowl survey in southern Moçambique, with conservation implications. In: Ledger J (ed.). Proceedings of the Fifth Pan-African Ornithological Congress, pp 639-664. Southern African Ornithological Society, Johannesburg.

Parker V 1999. The atlas of the birds of Sul do Save, southern Mozambique. Johannesburg \& Cape Town: Endangered Wildlife Trust \& Avian Demography Unit.

Parker V 2005. The atlas of the birds of Central Mozambique. Johannesburg \& Cape Town: Endangered Wildlife Trust \& Avian Demography Unit.

Peacock F 2012. Chamberlain's LBJs. Cape Town: Mirafra Publishing.

Pietersen DW, Pietersen EW. 2010. Annotated checklist of the birds of Banhine National Park, southern Mozambique. Ornithologi- 
cal Observations 1: 7-37. http://oo.adu.org.za/content.php? $\underline{i d=4}$.

Read C, Tarboton WR, Davies GBP, Anderson MD, Anderson TA. 2014. An Annotated Checklist of the Birds of The Vilanculos Coastal Wildlife Sanctuary, Southern Mozambique. Ornithological Observations 5: 370-408 http://oo.adu.org.zal content.php?id=155.

Richards R, Du Pasquier T. 1989 Bay whaling off southern Africa, c. 1785-1805. South African Journal of Marine Science 8(1): 231-250. DOI: 10.2989/02577618909504564

Rosa Pinto AA da, Lamm DW. 1953. Contribution to the study of the ornithology of Sul do Save (Mozambique). Memórias do Museu Dr Álvaro de Castro 2: 65-85.

Rosa Pinto AA da, Lamm DW. 1955. Contribution to the study of the ornithology of Sul do Save (Mozambique), Part II. Memórias do Museu Dr Álvaro de Castro 3: 125-159.

Rosa Pinto AA da, Lamm DW. 1956. Contribution to the study of the ornithology of Sul do Save (Mozambique), Part III. Memórias do Museu Dr Álvaro de Castro 4: 107-167.

Rosa Pinto AA da, Lamm DW. 1960. Contribution to the study of the ornithology of Sul do Save (Mozambique), Part IV. Memórias do Museu Dr Álvaro de Castro 5: 69-126.

Saraiva Okello AML, Masih I, Uhlenbrook S, Jewitt GPW, van der Zaag P, Riddell E. 2015. Drivers of spatial and temporal varia- bility of streamflow in the Incomati River basin. Hydrol. Earth Syst. Sci., 19: 657-673 https://doi.org/10.5194/hess-19-6572015.

Sinclair I, Ryan P. 2010. Birds of Africa south of the Sahara. $2^{\text {nd }}$ edition. Cape Town: Struik Nature, Cape Town.

Stalmans M, Wishart M. 2005. Plant communities, wetlands and landscapes of the Parque Nacional de Banhine, Mozambique. Koedoe 48(2): 43-58.

Timberlake JR, Dowsett-Lemaire F, Bayliss J, Alves T, Baena S, Bento C, Cook K, Francisco J, Harris T, Smith P, de Sousa C. 2009. Mt Namuli, Mozambique: Biodiversity and Conservation. Report produced under the Darwin Initiative Award 15/036. Royal Botanic Gardens, Kew, London. 114 p.

Timberlake JR, Bayliss J, Dowsett-Lemaire F, Congdon C, Branch WR, Collins S, Curran M, Dowsett RJ, Fishpool L, Francisco J, Harris T, Kopp M, de Sousa C. 2012. Mt Mabu, Mozambique: Biodiversity and Conservation. Report produced under the Darwin Initiative Award 15/036. Royal Botanic Gardens, Kew, London. 94 pp.

Tinley KL, Rosinha AJ, Tello JLPL, Dutton TP. 1976. Wild places in Mozambique. Oryx 13: 344-350.

Wild H, Barbosa L A Grandvaux. 1967. Vegetation map (1:2500000 in colour) of the Flora Zambesiaca area. Descriptive memoir. Salisbury, Rhodesia, Collins. 71 p. (Supplement to Flora Zambesiaca)

Afrotropical Bird Biology (ABB) is a free, open-access, online journal for articles that describe aspects of the natural and cultural history of birds in the Afrotropical region, including its offshore islands. These include, but are not restricted to, identification features, sounds, distribution and demography, movements, habitats, diseases and parasites, general habits, foraging and food, breeding, interactions with humans, human cultural beliefs and practices as they pertain to birds, moult and biometrics of birds. ABB publishes original contributions focused on presenting information about the natural history of Afrotropical birds. This includes short communications $(<2500$ words, including references) and data papers. All contributions will be reviewed by at least one editor and external, independent referees may also be employed at the discretion of the editors.

All papers are published under the Attribution-NonCommercial CC BY-NC license, which lets others remix, adapt, and build upon your work non-commercially, and although their new works must also acknowledge you and be non-commercial, they don't have to license their derivative works on the same terms. 
Annexe 1. eBird Bar chart of percentage frequency by week of all species recorded at the Macaneta- Wetlands eBird Hotspot. Downloaded from eBird hotspot link https://ebird.org/hotspot/L7097882. See this location for updated bar chart information.

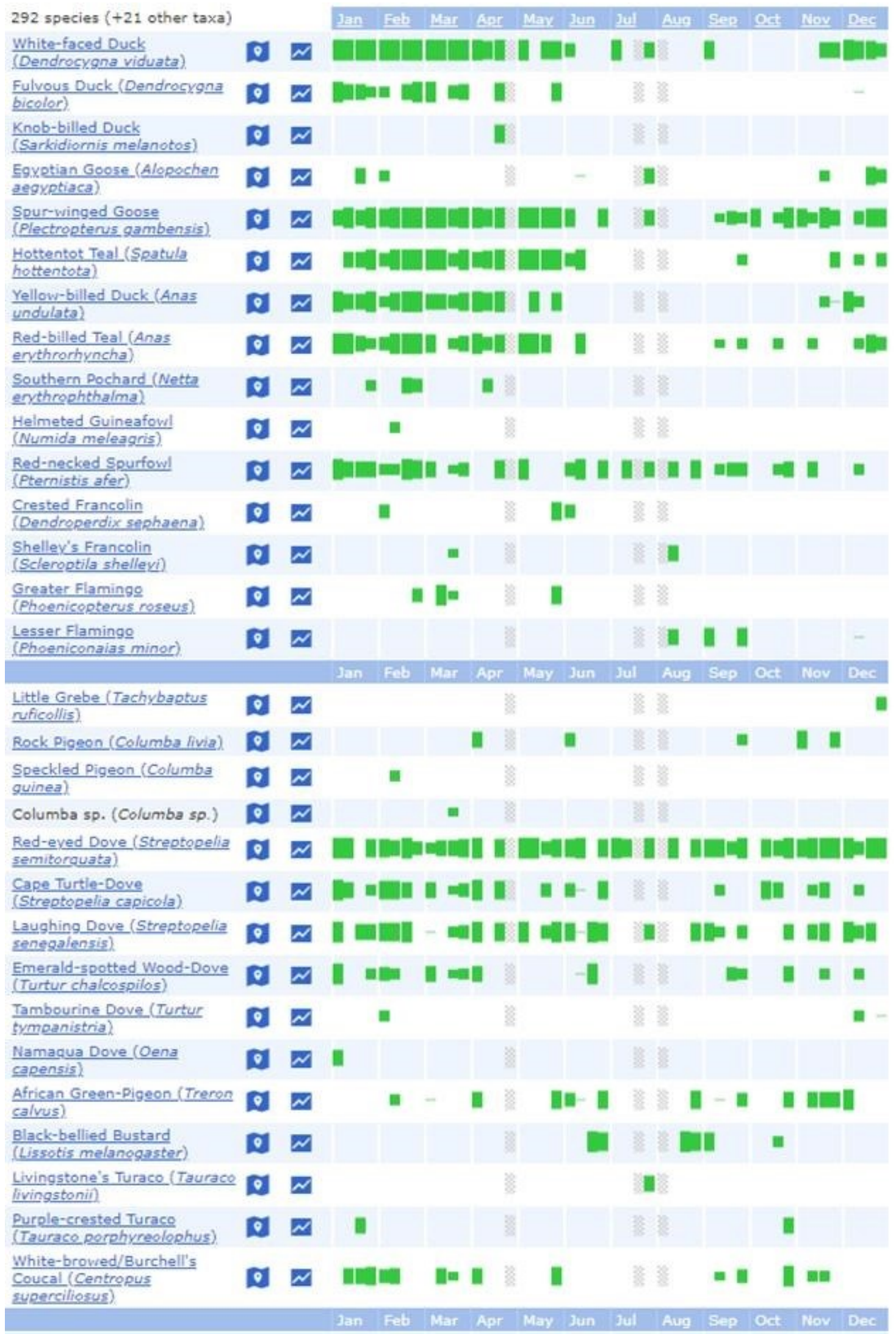




\begin{tabular}{|c|c|c|c|c|c|c|c|c|c|c|c|c|c|}
\hline & & & Jan & Feb & Mar Apr & May & Jun & Jul & Aug & Sep & Oct & Nov & Dec \\
\hline $\begin{array}{l}\text { Black Coucal (Centropus } \\
\text { grillii) }\end{array}$ & Q & $\omega$ & & 밈 & $=$ & & & 裙 & 愘 & & & & \\
\hline $\begin{array}{l}\text { Jacobin Cuckoo (Clamator } \\
\text { jacobinus). }\end{array}$ & 이 & $\mathbb{N}$ & & = & & & & 㐘 & 资 & & & & \\
\hline $\begin{array}{l}\text { Dideric Cuckoo } \\
\text { (Chrysococsyx caprius) }\end{array}$ & D & $\omega$ & & & a & & & 袹 & 数 & & - & 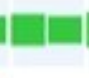 & al \\
\hline $\begin{array}{l}\text { Klaas's Cuckoo } \\
\text { (Chrysecoscyzx klaas) }\end{array}$ & 0 & $N$ & & & & & & 䇾 & 沮 & = & - & 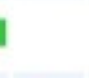 & - \\
\hline $\begin{array}{l}\text { Red-chested Cuckoo (Cuculus } \\
\text { solitarius). }\end{array}$ & Q & $M$ & & = & & & & 读 & 窟 & & & a & \\
\hline $\begin{array}{l}\text { Fiery-necked Nightjar } \\
\text { (Caprimu/gus pectoralis). }\end{array}$ & Q & $M$ & & E & - & & | & 紊 & 10 & & & = & \\
\hline $\begin{array}{l}\text { Square-tailed Nightjar } \\
\text { (Caprimu/gus fossii) }\end{array}$ & 0 & $M$ & & & & & 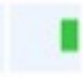 & 1 & 짐 & & & & \\
\hline $\begin{array}{l}\text { Caprimulgus sp. } \\
\text { (Caprimulgus sp.) }\end{array}$ & 0 & $N$ & 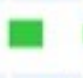 & च & $=$ & 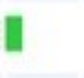 & & 疼 & 管 & & & & \\
\hline Common Swift (Aeus apus). & D & $\boldsymbol{N}$ & = & 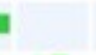 & & & & 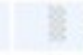 & 管 & & 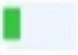 & & \\
\hline Little Swift (Aeus affinis). & 20 & $\boldsymbol{N}$ & & & al & & - & 签 & 曾 & aㅣㅁㅣ & - & I回 & 미 \\
\hline Horus Swift (ARus horus) & ? & 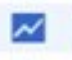 & ! & & - & & & 1 & 然 & & & & \\
\hline $\begin{array}{l}\text { White-rumped Swift (Apus } \\
\text { caffer). }\end{array}$ & 인 & $N$ & & & & a & & 娄 & 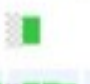 & & & & \\
\hline $\begin{array}{l}\text { African Palm-Swift (CXpsiurus } \\
\text { Rarvus) }\end{array}$ & 일 & 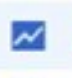 & & & & & & 1 & 1 & al & E. & ㅁaㅁ & 밈 \\
\hline swift sp. (Apodidae sp.) & (2) & $N$ & 政 & 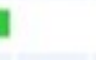 & & & 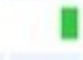 & 㽜 & 管 & & & & \\
\hline $\begin{array}{l}\text { Red-chested Flufftail } \\
\text { (Sarothrura rufa). }\end{array}$ & e & $\boldsymbol{N}$ & & & $=$ & & & 敕 & 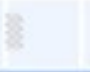 & & & & \\
\hline & & & Jan & Feb & Mar Apr & May & Jun & Jul & Aug & Sep & Oct & Nov & Dec \\
\hline $\begin{array}{l}\text { African Rail (Rallus } \\
\text { caerulescens). }\end{array}$ & 일 & $\boldsymbol{N}$ & ar. & & & & in & 1 & & = & & a & \\
\hline Corn Crake (Crex crex) & 인 & $N$ & & & & & & 美 & 登 & & & & 口 \\
\hline $\begin{array}{l}\text { Seotted Crake (Porzana } \\
\text { porzana) }\end{array}$ & 20 & $\mathbb{N}$ & 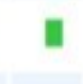 & a & = & & & 拻 & 䆖 & & & & \\
\hline $\begin{array}{l}\text { Lesser Moorhen } \\
\text { (Paragallinula anqulata). }\end{array}$ & D & $\omega$ & & ] & $=$ & a & & 袗 & 管 & & & & \\
\hline $\begin{array}{l}\text { Common Moorhen (Gallinula } \\
\text { chloroeus). }\end{array}$ & Q & $\omega$ & & 1돌 & & & - & 奠 & 零 & & & & - \\
\hline $\begin{array}{l}\text { Red-knobbed Coot (Fulica } \\
\text { cristata) }\end{array}$ & D & $\mathbb{N}$ & & & - & & & 簿 & 管 & & & & \\
\hline $\begin{array}{l}\text { Allen's Gallinule (Porehyrio } \\
\text { alleni). }\end{array}$ & Q & $\boldsymbol{N}$ & & a & Ee & 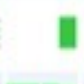 & & 美 & 尝 & & & & \\
\hline $\begin{array}{l}\text { African Swamphen (Porphyrio } \\
\text { madagascariensis) }\end{array}$ & D & $\boldsymbol{N}$ & & & & & & 望 & & $=$ & - & 田 & - \\
\hline $\begin{array}{l}\text { Black Crake (Zapornia } \\
\text { flavirostra). }\end{array}$ & 인 & $\boldsymbol{N}$ & & & 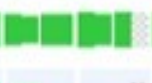 & & & - & 曾 & Fan & + & a & e \\
\hline $\begin{array}{l}\text { Baillon's Crake (Zapornia } \\
\text { pusilla). }\end{array}$ & Q & $\boldsymbol{N}$ & Eter & at & En= & a & & 8 & 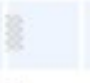 & & & a & \\
\hline $\begin{array}{l}\text { rail/crake sp. (Rallidae sp. } \\
\text { (rail/crake sp.)) }\end{array}$ & D & $\boldsymbol{N}$ & & ] & 田 & & & 2 & 得 & & & & \\
\hline $\begin{array}{l}\text { Water Thick-knee (Burhinus } \\
\text { vermiculatus). }\end{array}$ & 미 & $N$ & च & ] & - & a & & 18 & 管 & en & & & \\
\hline $\begin{array}{l}\text { Black-winged Stilt } \\
\text { (Himantopus himantopus) }\end{array}$ & (2) & $N$ & & & & & & & 10 & 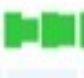 & 도 & a & \\
\hline $\begin{array}{l}\text { Pied Avocet (Recurvirostra } \\
\text { avosetta) }\end{array}$ & D & $\boldsymbol{N}$ & & & & & & 20 & 曾 & & & & $-\mathbf{a}$ \\
\hline \multirow[t]{2}{*}{$\begin{array}{l}\text { Grev Plover (Pluvialis } \\
\text { squatarola). }\end{array}$} & 이 & $N$ & & & & & & 20 & 送 & & & & 맘 \\
\hline & & & Jan & Feb & Mar Apr & May & Jun & Jul & Aug & Sep & Oct & Nov & Dec \\
\hline
\end{tabular}




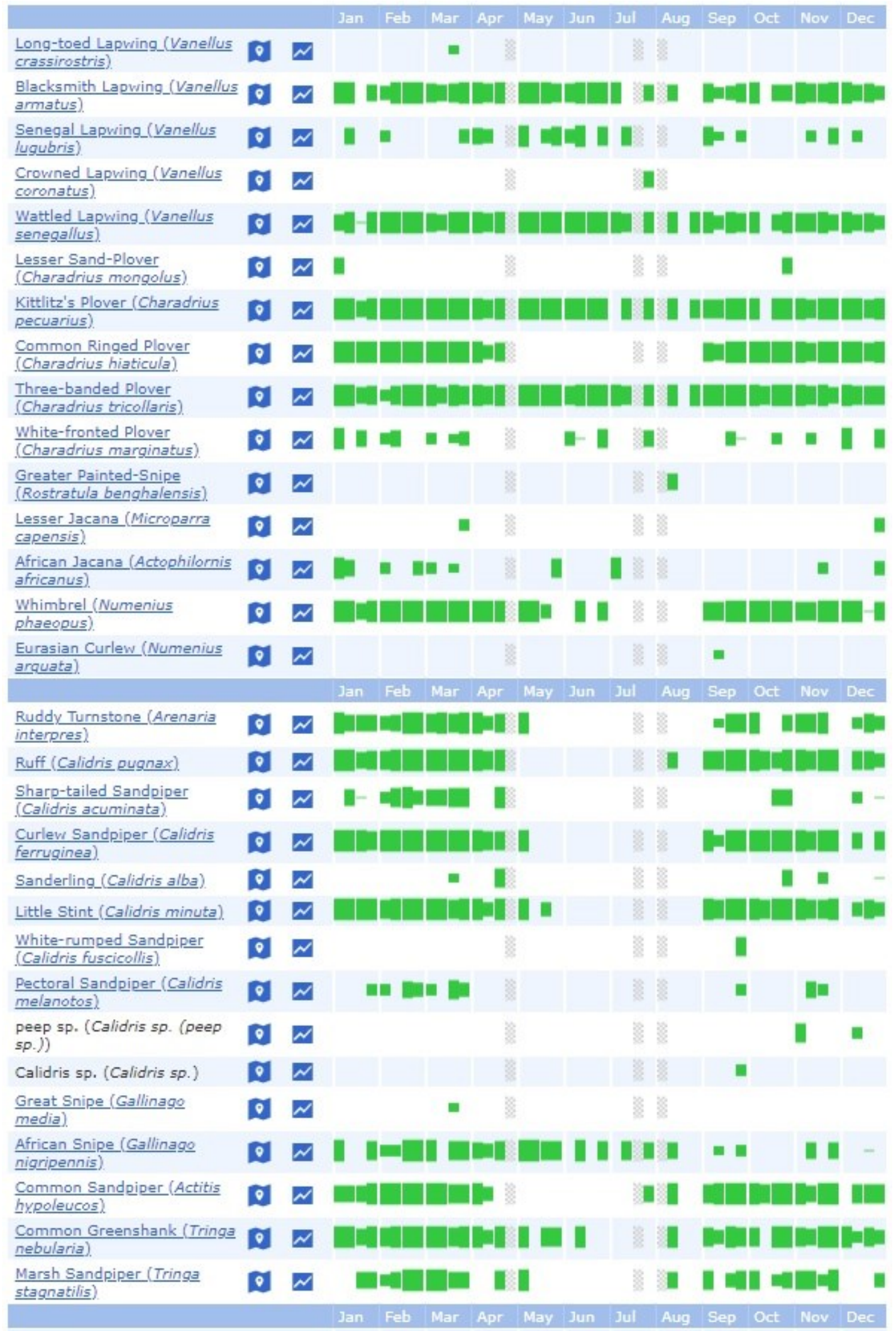




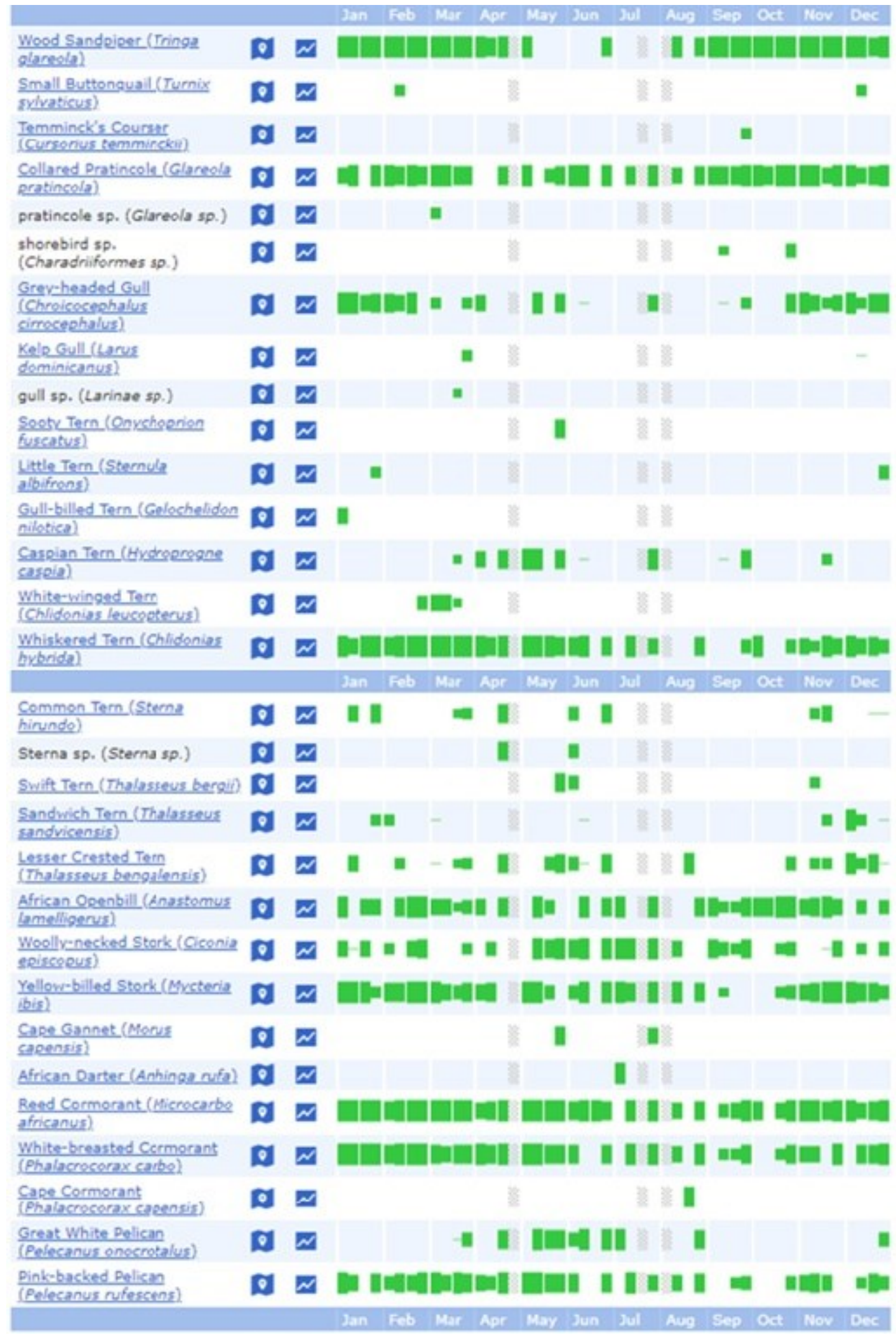




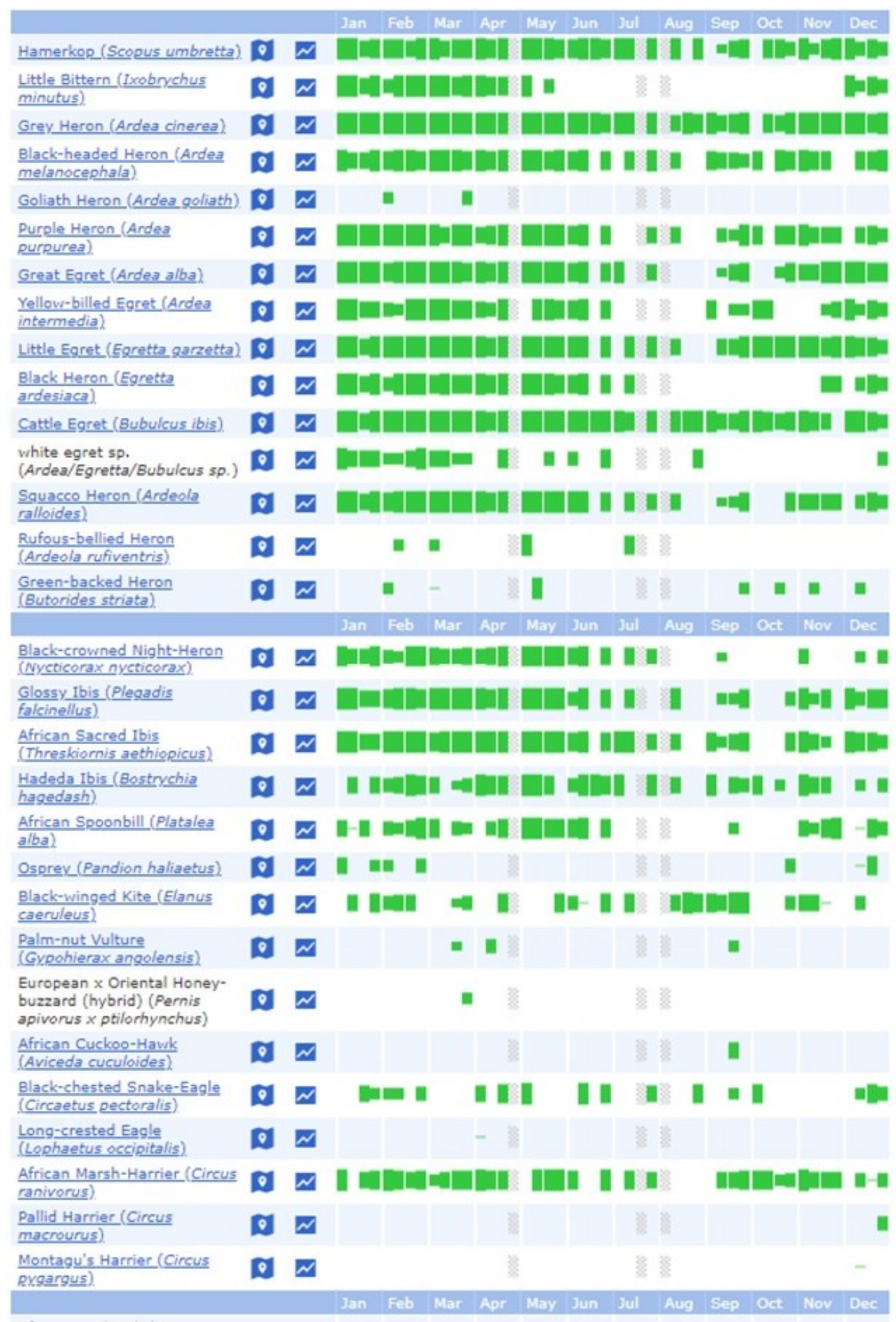




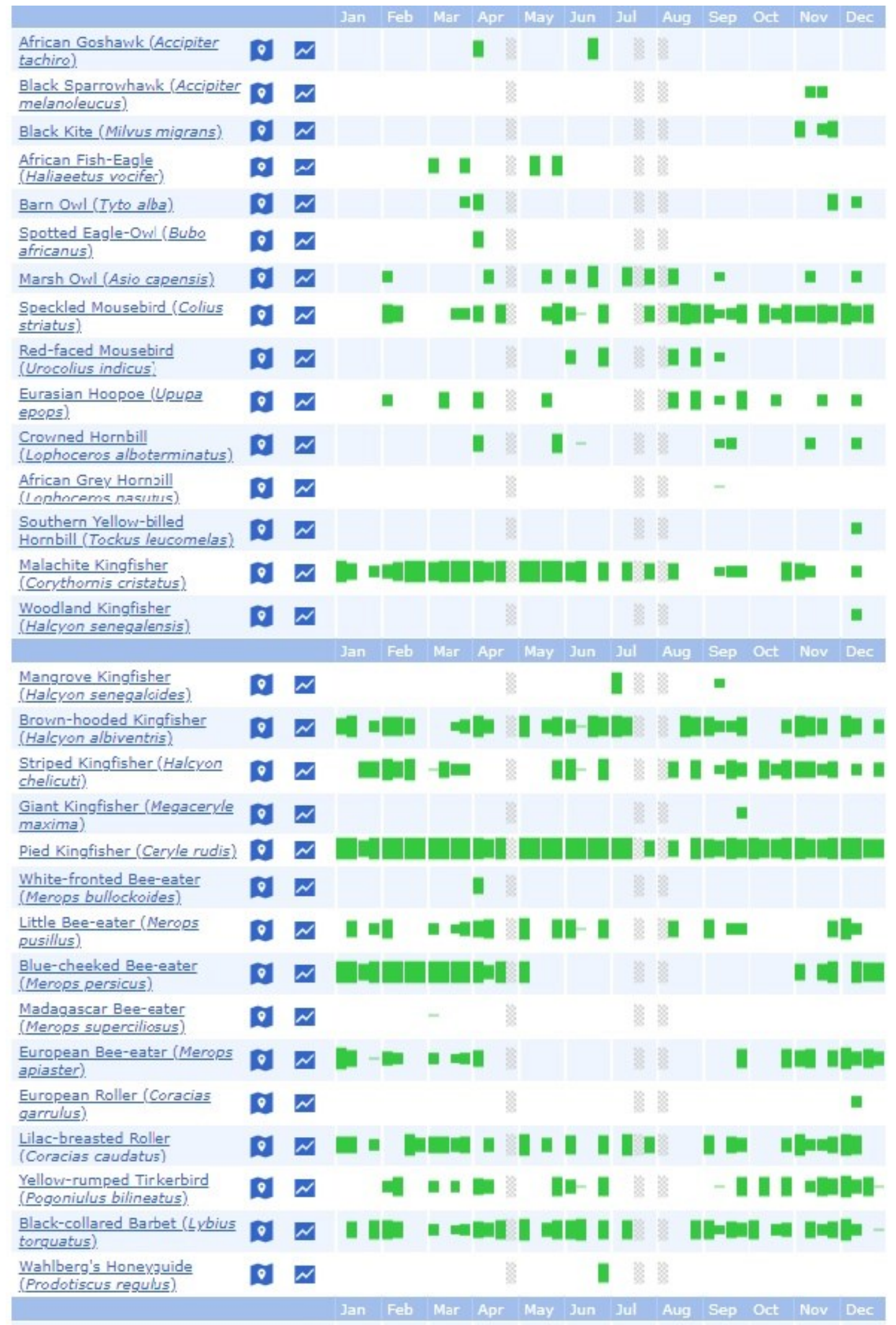




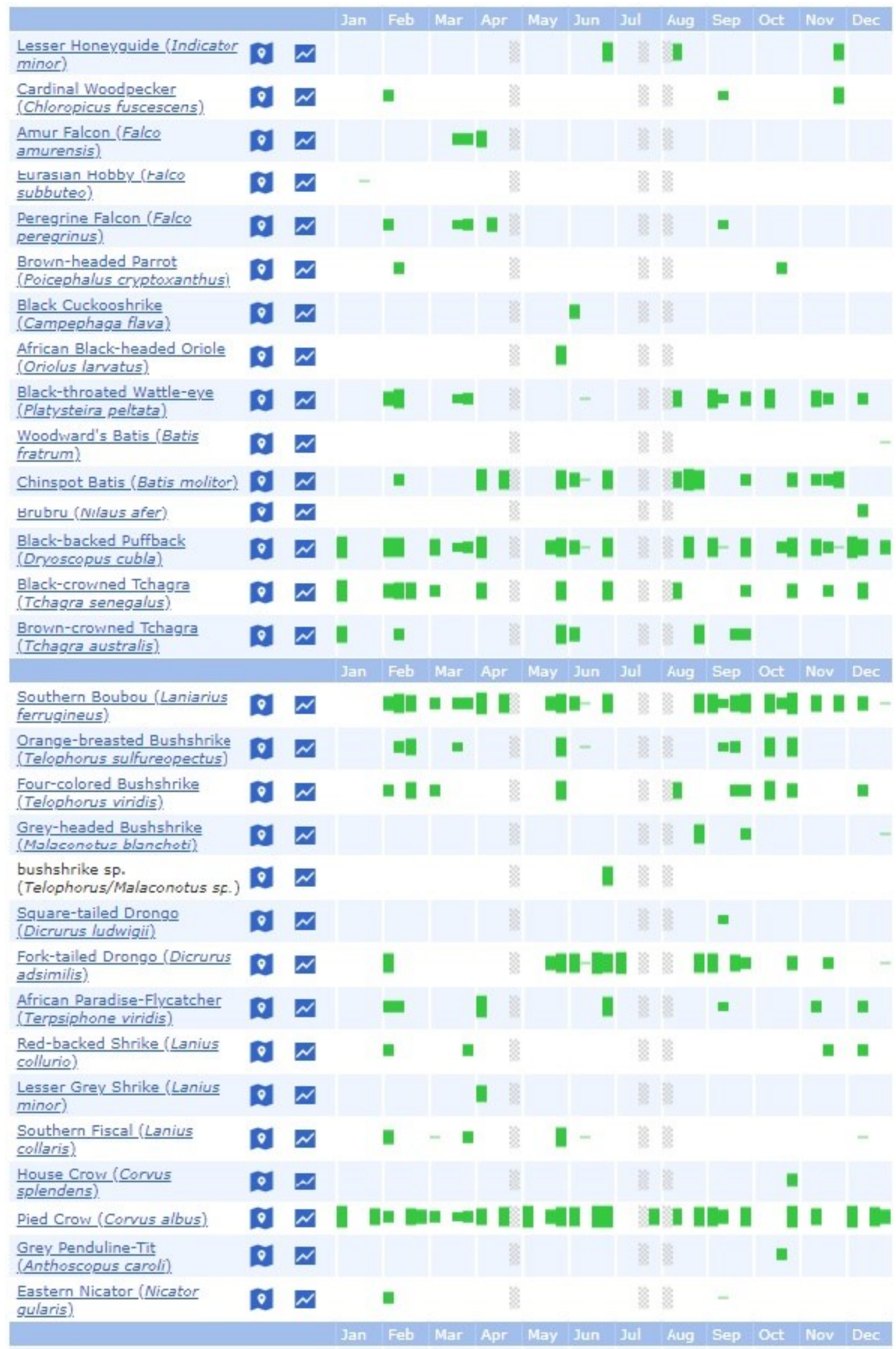




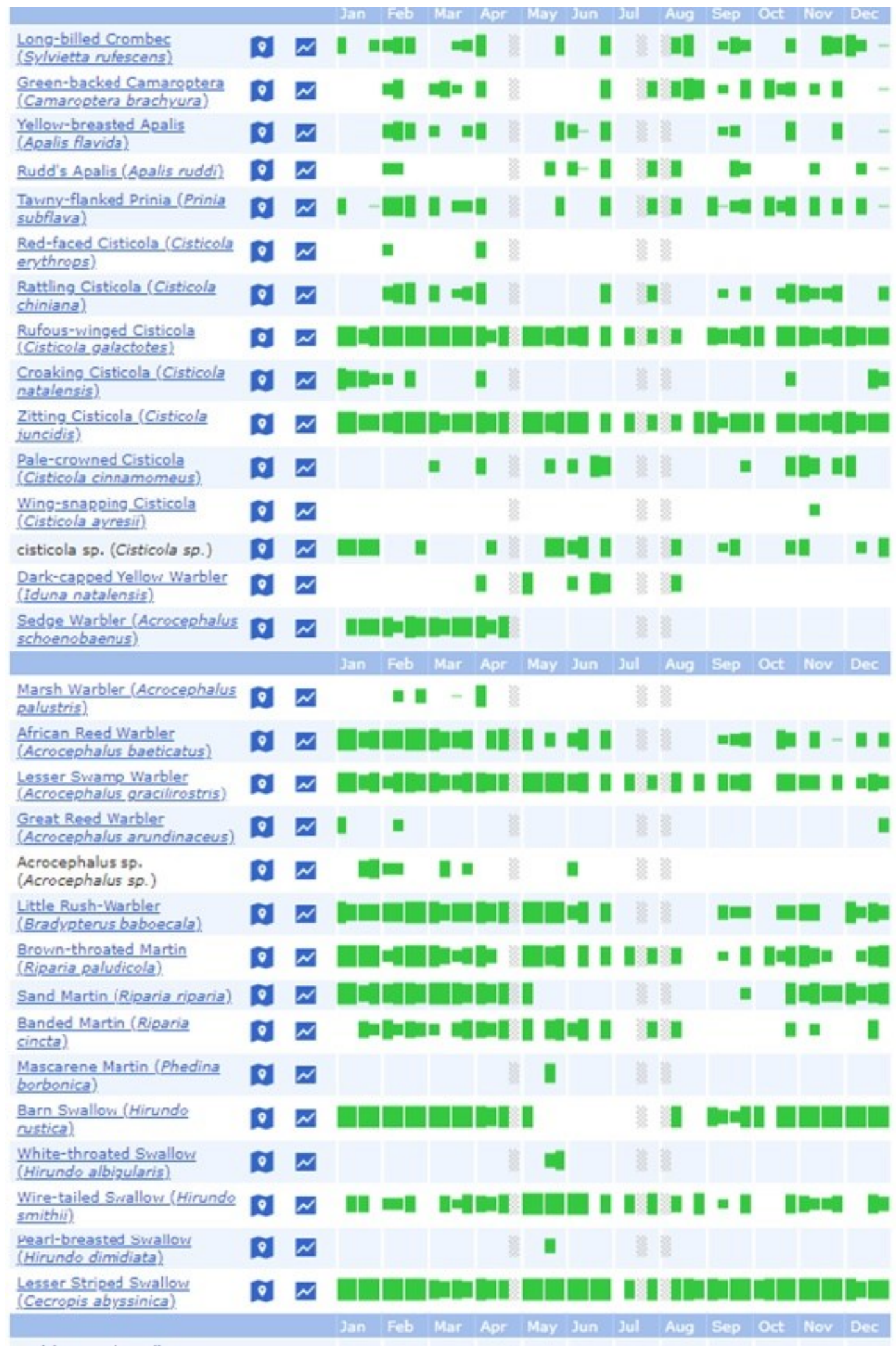




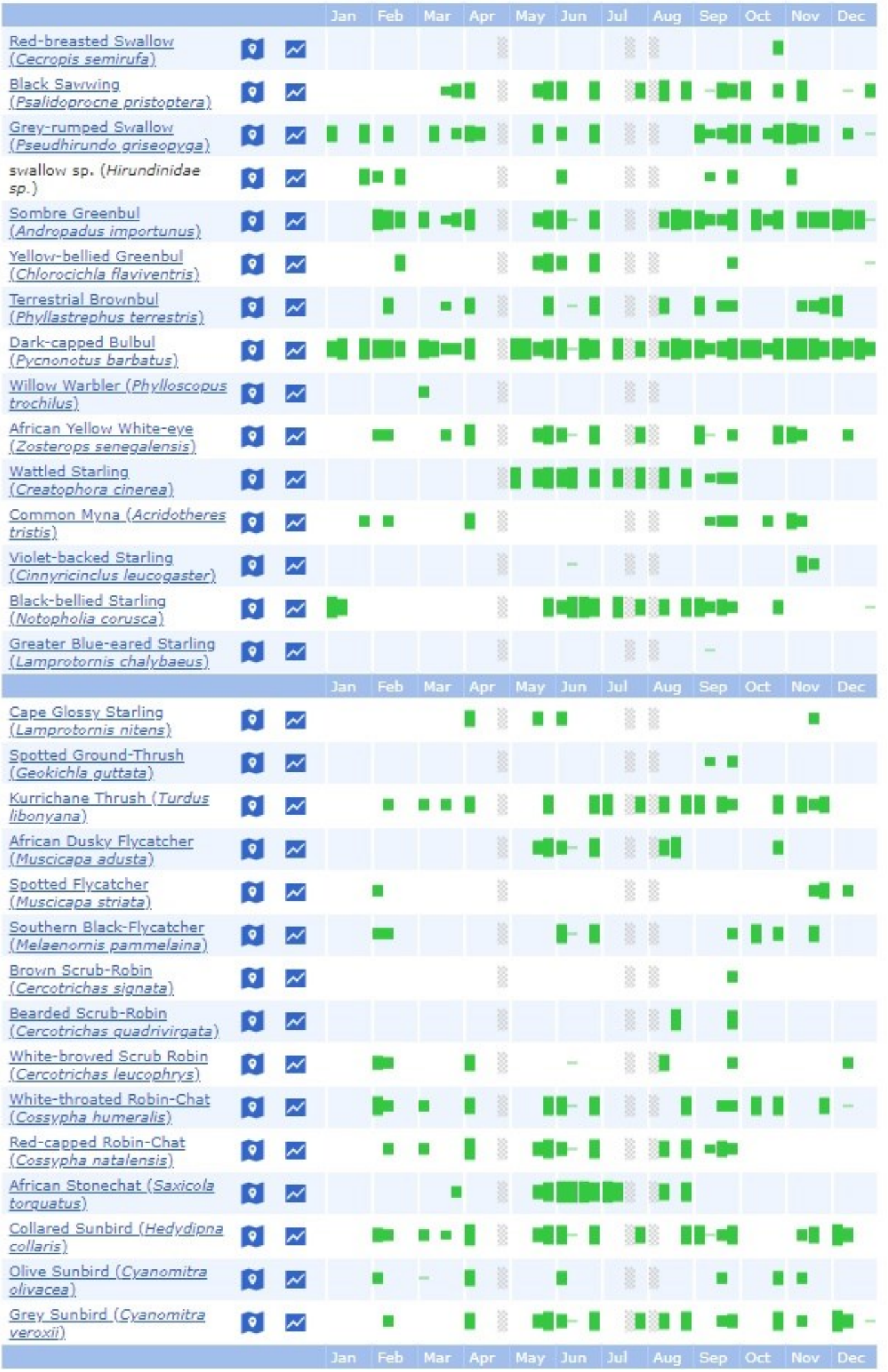




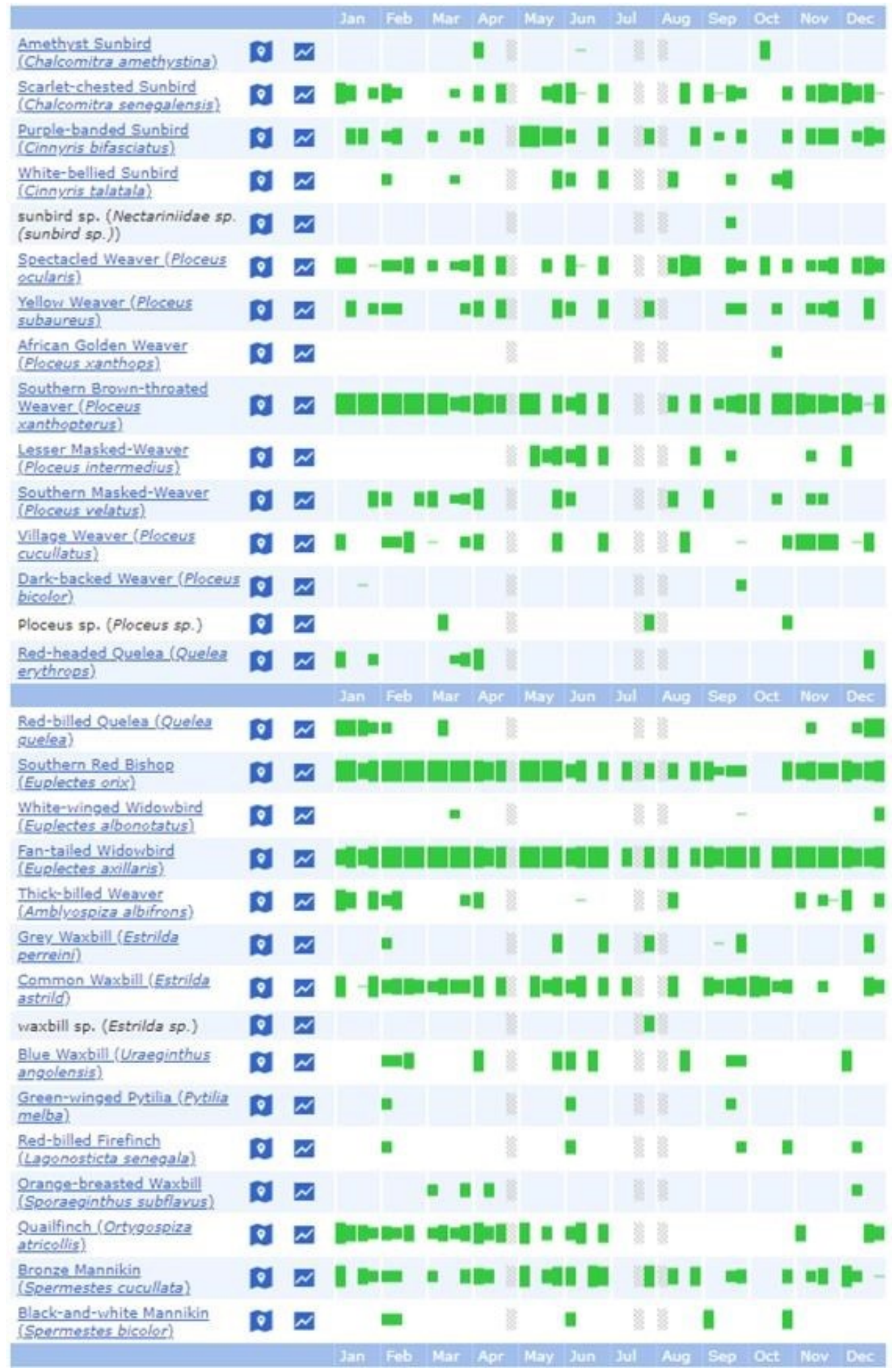




\begin{tabular}{l} 
Magpie Mannikin \\
$\begin{array}{l}\text { (Spermestes fringilloides). } \\
\text { Pin-tailed Whydah (Vidua }\end{array}$ \\
\hline macroura) \\
Vidua sp. (Vidua sp.)
\end{tabular}

